Original Article

\title{
PROTEOMIC ANALYSIS OF POLLEN AND BLOSSOM HONEY FROM RAPE SEED BRASSICA NAPUS L.
}

\author{
Veronika Borutinskaitè ${ }^{1}$ \\ Gražina Treigytè ${ }^{1}$ \\ Dalius Matuzevičius² \\ llona Zaikova ${ }^{1}$ \\ Violeta Čeksterytè ${ }^{3}$ \\ Dalius Navakauskas² \\ Bogumila Kurtinaitienè ${ }^{1}$ \\ Rūta Navakauskienè ${ }^{1 *}$ \\ ${ }^{1}$ Institute of Biochemistry, Life Science Center, Vilnius University \\ ${ }^{2}$ Electronic Systems Department, Faculty of Electronics, Vilnius Gediminas Techni- \\ cal University \\ ${ }^{3}$ Lithuanian Research Centre for Agriculture and Forestry, Institute of Agriculture \\ *corresponding author: ruta.navakauskiene@bchi.vu.lt \\ Received: 05 May 2016; accepted: 29 April 2017
}

\section{Abstract}

In the study, honey from oilseed rape Brassica napus L., and both hand-collected (winter rape Visby and Cult) and bee-collected pollen of oilseed rape were analyzed for their proteome content, in order to see if any plant proteins were present to allow the proteo-typing of the oilseed rape honey. Proteins were fractionated by two-dimensional gel electrophoresis (2DE), stained by Coomassie blue and then analyzed by mass spectrometry. All identified proteins were divided into few groups due to their biological function. In 2DE gels with separated proteins from blossom honey, only bee (Apis mellifera) main proteins (Major royal jelly protein 1-5 and Glucosidase) were found. So we analyzed all proteins using gel-free based analysis with the SYNAPT G2 high definition mass spectrometry. We identified proteins that were present in both oilseed rape pollen and honey (Bna, Polygalacturonase, Non-specific lipid-transfer protein, GAPDH and others). We believe that these proteins are important for the nutritional value of plant pollen-enriched honey and further research is required on honey and honeybee pollen protein.

Keywords: Brasica napus L., honey, honeybee pollen, proteomics, rape

\section{INTRODUCTION}

In recent years, there has been an increased demand for honeybee pollen as a healthy food supplement. The content of protein, fat, phosphorus, iron and vitamins $\left(E, D, B_{12}\right)$ makes pollen's nutritive value comparable to dried beans or beef (Erlund, 2004). The unique properties of pollen were one of the reasons for using it as a pharmaceutical preparation. It was also important whether pollen was gathered by hand directly from the flower or by bees which is particularly rich in vitamins with a far higher concentration of pantothenic acid. The German Federal Board of Health has officially recognized the use of pollen as medicine; pollen has been helpful when administered in cases of chronic prostatitis (Cai et al., 2014; Wagenlehner et al., 2009).

Some chronic diseases such as cancer, coronary, and neurological degeneration have been reported to be a consequence of oxidative damage (Babizhayev, Vishnyakova, \& Yegorov, 2014; Jiang, Sun, \& Chen, 2016). The therapeutic potential of honey is almost always associated with the antioxidant capacity against reactive oxygen species (Ferreira et al., 2009). Therefore, in recent years, studies have been focused on the composition of honeys and their biological properties such as antioxidant, anti-inflammatory and antimicrobial activities in wound healing, as well as in the treatment of 


\section{Rape pollen and honey proteomic analysis}

skin ulcers and gastrointestinal disorders (AlMamary, Al-Meeri, \& Al-Habori, 2002; Tonks et al., 2003; Brudzynski \& Kim, 2011; Nasir et al., 2010; Erejuwa, Sulaiman, \& Wahab, 2012).

Oilseed rape (Brassica napus) is one of the most cultivated crop plants around the world. It is an important source of oil and medicinal components. The cultivation rate of oilseed rape around the globe has been increasing over the last ten years with about 31.5 Mha of lands used to cultivate in 2010 (Gulden, Warwick,\& Thomas, 2008; Islam et al., 2013).

Rape seed (Brassica napus L.) crops and honey are very good and commonly used bee food. Its pollen contains such amino acids as Threonine, Valine and Methionine and $23 \%$ to $24 \%$ crude protein, but the exact content is not exactly known. Honey differs in its composition due to plant contribution and environmental conditions; the honey properties depend on the nectar/ pollen of the original plant, colour, flavour, moisture or sugar contents (da Silva et al., 2016). Not much is known about the protein content of honey. In recent years a great deal of information has published about proteins that could be allergens in oilseed rape pollen (Chardin et al., 2001; Focke et al., 2003; Poikonen et al., 2006). The aim of this study was to identify protein content and composition of the pollen from oilseed rape (Brassica napus L.) honey as well as hand-collected and bee-collected rape pollen and to classify detected proteins according their biological function.

\section{MATERIAL AND METHODS}

\section{Collection of pollen from rape}

Rape pollen grains for the study were collected either by hand from flowers or from pollen traps. All pollen samples were collected from the experiment fields of the Lithuanian Research Centre for Agriculture and Forestry, Institute of Agriculture in Kèdainių district, Lithuania. Mature pollen grains were hand-collected from freshly open winter rape Cult blossoms into Eppendorf tubes and stored at $-80^{\circ} \mathrm{C}$ until analysis. Rape pollen gathered by bees was collected in accordance with good beekeeping practices and did not interfere with normal colony growth (Gracham, 1992). Honeybeegathered pollen was collected from a standard pollen trap mounted on the hive entrance in good weather during rape blossoming. After removal from traps, the pollen was cleaned and kept in a refrigerator at $-80^{\circ} \mathrm{C}$ in air-tight plastic bags.

\section{Monofloral honey samples}

Monofloral rape honey was harvested from bee colonies located in the Kedainių district, Lithuania and used in this study. Honey samples were preserved in glass bottles and refrigerated $\left(5^{\circ} \mathrm{C}\right)$ until analysis.

\section{Protein isolation from pollen}

Proteins from mature pollen (approx. $20 \mathrm{mg}$ ) were isolated as described by Sheoran et al., (2007) with some modifications. Briefly, mature pollen was homogenized with acetone containing $10 \%$ trichloroacetic acid (TCA) and $1 \%$ dithiothreitol (DTT). The solution was centrifuged $20.000 \times \mathrm{g}$ for $20 \mathrm{~min}$ at $4^{\circ} \mathrm{C}$. The supernatant was collected as the first extract and pellet of pollen remains was washed two times more with acetone solution containing 1\% DTT. The pellet was dried in a vacuum and proteins were extracted with isoelectric focusing (IEF) Iysis buffer, the second extract. After centrifugation, both extracts were combined and directly used for protein analysis or stored at $-20^{\circ} \mathrm{C}$ until analysis.

\section{Protein isolation from honey samples}

The honey samples $(0.2 \mathrm{~g} / \mathrm{ml})$ were dissolved in distilled water, centrifuged at 3000 rpm for $20 \mathrm{~min}$ (K-24) and filtered on glass fibre prefilter (Millipore, 5-15 $\mu$ ) under vacuum. The carbohydrate was removed using a capillary dialyzer Xevonta Lo 20 (B. Braun, Avitum, Melsungen, Germany). Part of the solution was concentrated about three times in a dialysis tubing VISKING (Serva, Heidelberg, Germany), keeping onto dry polyethylene glycol (PEG). Proteins were precipitated by adding four volumes of cold $80 \%$ acetone and incubated overnight at $-20^{\circ} \mathrm{C}$. The pellet was then washed with $1 \mathrm{ml}$ chilled $80 \%$ 
acetone several times. The pellet was dried for 5 min at room temperature, suspended in IEF buffer as described above and stored at $-20^{\circ} \mathrm{C}$ until analysis.

\section{Electrophoretic separation of proteins by SDS/PAGE and 2DE}

The proteins isolated from hand- and beecollected pollen and rape honey were fractionated by SDS/PAGE on gradient (7.5 - 15\%) polyacrylamide gel and also resolved by twodimensional gel electrophoresis (2DE). An Immobiline DryStrip kit, pH range 3-11, and Excel gel SDS, gradient 8-18\% was conducted for 2DE according to the manufacturer's instructions (Immobiline DryStrip kit for 2DE with Immobiline DryStrip and Excel gel SDS, Pharmacia Biotech, Sweden). For protein visualization, the gels were stained with Colloidal Coomassie G-250 (Bio-Rad Laboratories, USA). For 2DE fractionation of pollen proteins, three independent biological experiments were carried out.

\section{In-gel digestion and MALDI-TOF MS}

Areas of interest were cut out from the 2DE gels and subjected to overnight in-gel tryptic digestion (Shevchenko et al., 1996). For MALDI-TOF analysis, the peptides were prepared and mass spectrometry analysis performed.

\section{Protein sample preparation and mass spec- trometry analysis}

Extracted proteins from hand- and bee-collected pollen as well as rape honey proteins were analysed by direct gel-free mass spectrometry analysis. For this, isolated proteins were applied on Amicon Ultra-0.5 mL 30 kDa centrifugal filter unit (Sigma-Aldrich, USA). Trypsin digestion was done according to a modified FASP protocol as described by Wisniewski et al., (2009).

\section{Data processing, searching and analysis}

Raw data files were processed and examined using ProteinLynx Global SERVER (PLGS) version 2.5.2 (Waters Corporation, UK). The following parameters were used to generate peak lists: (i) minimum intensity for precursors set to 100 counts, (ii) minimum intensity for fragment ions set to 30 counts, (iii) intensity set to 500 counts. Processed data was analyzed using trypsin as the cleavage protease, one missed cleavage was allowed and fixed modification was set to carbamidomethylation of cysteines, and variable modification was set to the oxidation of methionine. Minimum identification criteria included two fragment ions per peptide, five fragment ions per protein and a minimum of two peptides per protein. The false discovery rate (FDR) for peptide and protein identification was determined based on the search of a reversed database, which was generated automatically using PLGS when the global false discovery rate was set to $1 \%$. Functional protein association networks were constructed using AgBase, version 2.00 (agbase.msstate.edu).

\section{Gel scanning and image analysis}

The 2DE gels with visualized proteins were scanned using a specialized gel imaging system whose components were ImageScanne ${ }^{\mathrm{TM}}$ III (GE Healthcare Bio-Sciences, UK) and LabScan v6.0 sofware. The scanner was calibrated using the provided step tablet with the known optical density values. Gels were digitized at 16-bit pixel depth and 300 dpi resolution, and stored as TIFF ${ }^{\mathrm{TM}}$ format graphic files.

The scanned 2DE gel images were analysed using our developed software toolset which runs in the Matlab ${ }^{\text {TM }}$ environment (The MathWorks, Natick MA, USA). It included custom image pre-processing, alignment, segmentation, spot pairing, successive data analysis and visualization instruments. Our workflow of gel image analysis was based on one of the common procedures where image segmentation was performed after image registration. A more detailed sequence of operations was as follows: image pre-processing, spot detection in individual images, image registration, spot detection in the set of aligned images and spot pairing, extraction of spot boundaries in the original images, spot quantitation and differential analysis.

Image pre-processing algorithms cope with intensity distortions caused by impulse noise (randomly occurring clearly brighter and darker 
pixels) and non-uniform background (slowly varying background intensity level). Additionally, gel images are cropped to remove excessive areas that are not useful for the image registration. Image registration is based on feature matching strategy and has coarse and fine stages. Detected features are likely locations of protein spots, where local feature descriptors should be extracted. Paired features serve as control points for the initial rigid deformation of gels. Fine image registration detects refined correspondences between gels and performs elastic thin-plate spline transformation (Bookstein, 1989) to put matching spots into the same locations.

Gel images must be segmented (Serackis \& Navakauskas, 2010) and corresponding segments be found to enable a quantitative comparison of spots from different 2DE gel images (Dowsey et al., 2010; Valledor \& Jorrín, 2011). Performing spot detection on registered images allows us to achieve improved results compared to spot detection in original gels separately. Spot detection provides only probable positions of protein spots. Spot segmentation gives information on spot boundaries and is performed in original undistorted gels. Segmentation is guided by spot location information that was extracted during an earlier detection stage. Segmentation gives spot boundaries and area for the integration of the spot intensity, i.e. spot volume. Collected data on protein spot area and matchings between gels is used to perform differential analysis. Ratios of normalized spot quantities describe the differences between experimental groups.

\section{RESULTS}

The soluble proteins extracted from oilseed rape blossom honey, hand-collected oilseed rape pollen and bee-collected oilseed rape pollen were analyzed in three different ways (Fig. 1); proteins were separated by either SDS-PAGE or by 2DE on $\mathrm{pH}$ 3-11 IPG strips and stained

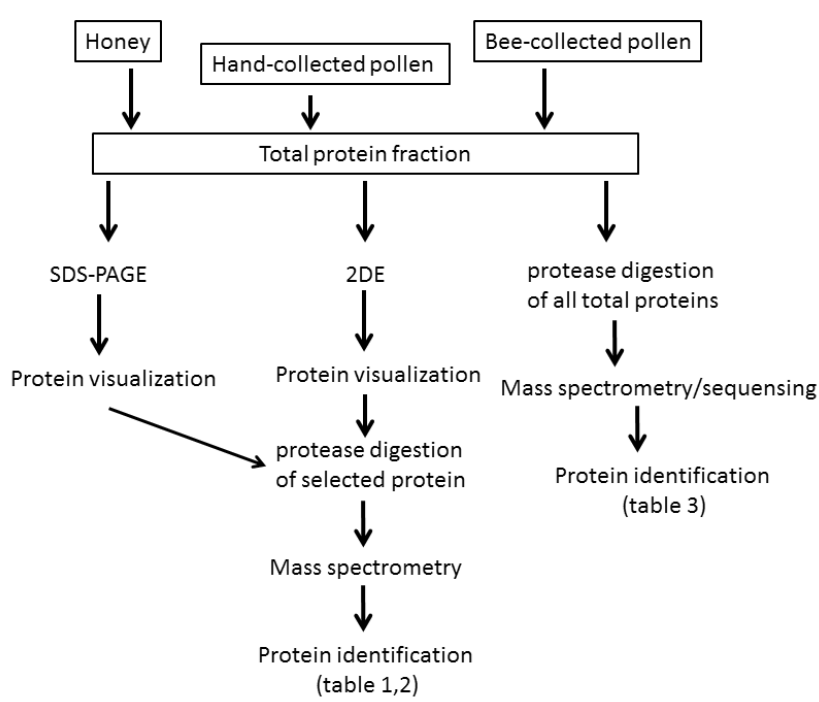

Fig. 1. Scheme of protein separation and identification from hand- or bee-collected pollen and honey samples. Samples from oilseed rape (Brassica napus) hand- and bee-collected pollen or honey were separated on SDS-PAGE (1DE) and 2DE system and then subjected to mass spectrometry analysis.

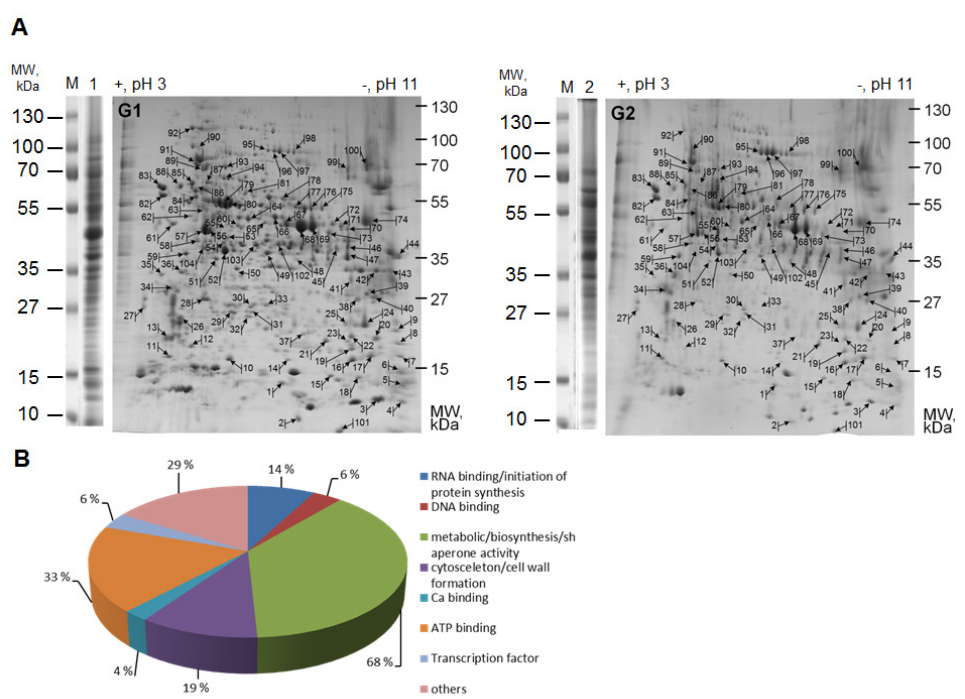

Fig. 2. Quantitative analysis of the proteins from handand bee- collected Brassica napus pollen. Proteins from hand- (G1, winter rape Cult) and bee- (G2) collected pollen were fractionated by ordinary SDS/PAGE ( $A$, lines 1 and 2) and by $2 D E(A, G 1$ and $G 2)$. Protein maps representing hand- (G1) and bee- (G2) collected Brassica napus pollen were overlapped and quantitative changes in protein levels were evaluated by computer-assisted analysis (Table 1). Numbers in the 2DE maps indicate the positions of proteins supplied to MALDI-224 TOF MS/MS and identified. Spot labels are the same as in Table 1. Representative images from one of the three experiments showing similar results are shown. Part B represents protein functions of Brassica napus pollen, fractionated by 2DE and identified by MS. 
Table 1

Proteins identified from hand- and bee-collected Brassica napus by MS.

$A C$

No. [accession Description of protein [protein name, organism] number]

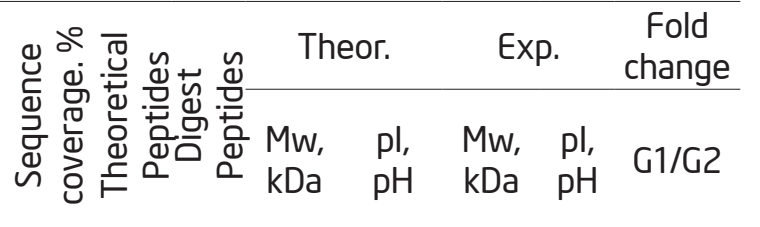

\begin{tabular}{|c|c|c|}
\hline 3 & A1EA43 & $\begin{array}{c}\text { Translation initiation factor IF-1, chloroplastic } \\
\text { OS=Agrostis stolonifera }\end{array}$ \\
\hline 8 & P42794 & $\begin{array}{c}605 \text { ribosomal protein L11-2 OS=Arabidopsis } \\
\text { thaliana }\end{array}$ \\
\hline 13 & P43349 & $\begin{array}{c}\text { Translationally-controlled tumor protein homolog } \\
\text { OS=Solanum tuberosum }\end{array}$ \\
\hline 20 & P34944 & $\begin{array}{l}\text { NADH dehydrogenase [ubiquinone] iron-sulfur } \\
\text { protein } 3 \text { OS=Marchantia polymorpha }\end{array}$ \\
\hline 23 & P49208 & $\begin{array}{l}50 \text { S ribosomal protein L1, chloroplastic } \\
\text { (Fragment) OS=Pisum sativum }\end{array}$ \\
\hline 28 & P21216 & $\begin{array}{c}\text { Soluble inorganic pyrophosphatase } 2 \\
\text { OS=Arabidopsis thaliana }\end{array}$ \\
\hline 33 & Q38829 & $\begin{array}{l}\text { Auxin-responsive protein IAA11 OS=Arabidopsis } \\
\text { thaliana } \\
\text { Cyclic pyranopterin monophosphate synthase }\end{array}$ \\
\hline
\end{tabular}

37 Q39056 accessory protein, mitochondrial OS=Arabidopsis thaliana

46 F6HDM2 ATP-dependent (S)-NAD(P)H-hydrate dehydratase OS= Vitis vinifera

50 Q9M7I7 Chlorophyllase-2, chloroplastic OS=Arabidopsis thaliana

$\begin{array}{llllllll}7.7 & 26 & 2 & 12.45 & 9.52 & 12.2 & 8.4 & 3.6\end{array}$

$\begin{array}{llllllll}11.4 & 35 & 4 & 20.84 & 9.94 & 17.3 & 9.3 & 3.3\end{array}$

$\begin{array}{llllllll}21.1 & 19 & 4 & 18.83 & 4.58 & 18.1 & 4.5 & 3.0\end{array}$

$\begin{array}{llllllll}12.5 & 24 & 3 & 23.33 & 6.21 & 17.9 & 8.3 & 3.4\end{array}$

$\begin{array}{llllllll}2.6 & 39 & 1 & 23.48 & 10.2 & 17.6 & 7 & 4.2\end{array}$

$\begin{array}{llllllll}3.4 & 29 & 1 & 24.65 & 5.72 & 23.9 & 5 & 5.5\end{array}$

$\begin{array}{llllllll}13.8 & 29 & 4 & 26.49 & 5.82 & 22.9 & 5.8 & 9.2\end{array}$

$\begin{array}{llllllll}16.7 & 36 & 6 & 29.49 & 8.22 & 18.6 & 6.3 & 6.3\end{array}$

$\begin{array}{llllllll}4.8 & 42 & 2 & 38.08 & 8.3 & 36.4 & 7.1 & 3.9\end{array}$

$\begin{array}{llllllll}15.2 & 33 & 5 & 34.88 & 6.5 & 29.8 & 5.5 & 3.6\end{array}$

51 Q9SID0 Probable fructokinase-1 OS=Arabidopsis thaliana

55 Q9SRT9 UDP-arabinopyranose mutase 1 OS=Arabidopsis thaliana Chaperonin CPN60, mitochondrial OS=Arabidopsis thaliana

87 P29197 of RNA polymerase II transcription subunit $37 \mathrm{f}$ OS=Arabidopsis thaliana

$\begin{array}{llllllll}15.8 & 38 & 6 & 35.25 & 5.31 & 32.9 & 5.2 & 3.7\end{array}$

$\begin{array}{llllllll}25.6 & 39 & 10 & 40.60 & 5.61 & 42.6 & 5.3 & -6.0\end{array}$

$\begin{array}{llllllll}7.9 & 76 & 6 & 61.24 & 5.66 & 65.6 & 5.1 & 5.0\end{array}$

$\begin{array}{llllllll}22.3 & 94 & 21 & 73.51 & 5.11 & 92.5 & 4.9 & -3.8\end{array}$

5-methyltetrahydropteroyltriglutamate--homo-

95050008 cysteine methyltransferase 1 OS=Arabidopsis thaliana

5-methyltetrahydropteroyltriglutamate--homo-

96050008 cysteine methyltransferase 1 OS=Arabidopsis thaliana

102 Q9FHD5 Cysteine-rich repeat secretory protein 57 $\mathrm{OS}=$ Arabidopsis thaliana

DNA-directed RNA polymerase subunit alpha

$$
\text { OS=Pisum sativum }
$$

$\begin{array}{llllllll}17.2 & 87 & 15 & 84.30 & 6.09 & 89.6 & 5.8 & -3.4\end{array}$

$\begin{array}{llllllll}19.5 & 87 & 17 & 84.30 & 6.09 & 89.3 & 5.8 & -4.1\end{array}$

$\begin{array}{llllllll}22.7 & 22 & 5 & 31.85 & 5.56 & 37.2 & 5.8 & 3.2\end{array}$

$\begin{array}{llllllll}16.3 & 43 & 7 & 38.90 & 7.2 & 36.9 & 5.7 & 7.4\end{array}$

$\begin{array}{llllllll}15.0 & 40 & 6 & 39.15 & 5.67 & 36.1 & 5 & 3.2\end{array}$ with CCB and then mass spectrometry were prepared, or soluble proteins were analysed by direct gel-free mass spectrometry analysis using HDMS Synapt G2 mass spectrometer.

Protein profile comparison from hand-col- lected and bee-collected oilseed rape pollen We aimed to characterize the difference in proteome maps between hand-collected (Fig. 2A, G1) and bee-collected (Fig. 2A, G2) oilseed rape pollen. Over 200 spots were detected using $\mathrm{pH}$
3-11 IPG strips (Fig. 2A, G1/G2) and analysed 

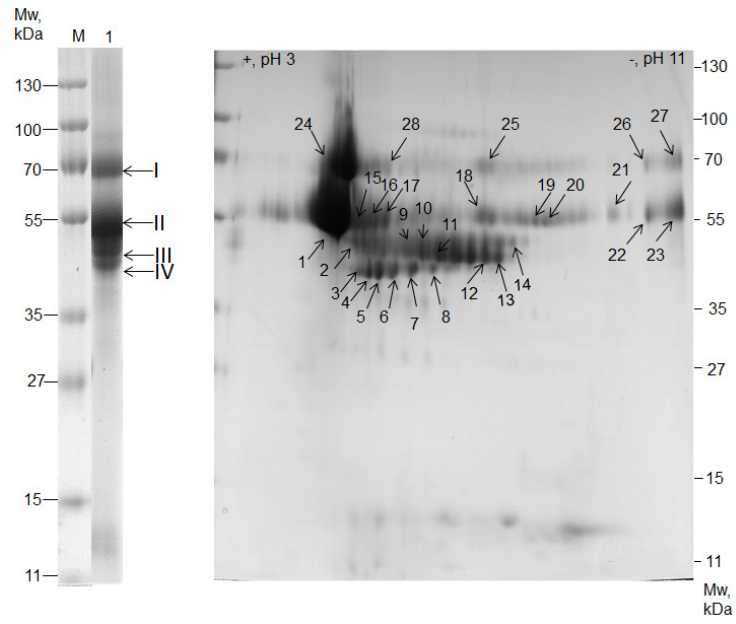

Fig. 3. Analysis of the proteins from Brassica napus honey. Proteins were fractionated by ordinary SDS/PACE (lines 1) and by $2 D E$. Numbers in the SDS-PAGE and 2DE maps indicate the positions of proteins supplied to MALDI-224 TOF MS/MS and identified. Spot labels are the same as in Table 2. Representative images from one of the three experiments showing similar results are shown. by MALDI-TOF MS, of which 107 spots were successfully analysed (Fig. 2A, G1/G2). The identified proteins, along with the protein index, MW, pl, and the fold change between G1 (handcollected pollen), G2 (bee-collected pollen) and protein fold change between G1 and G2 are listed in Supplement 1. Some of the identified proteins were present as multiple spots on gels that could correspond to multiple isoforms of protein. Almost all proteins isolated from handand bee- collected oilseed rape pollen showed similar protein content, but some showed quantitative differences and are listed in Table 1. Translation initiation factor IF-1 (no. 3), 50S ribosomal protein L1 (no. 23), Soluble inorganic pyrophosphatase 2 (no. 28), Auxin-responsive protein (no. 33), Cyclic pyranopterin monophosphate synthase accessory protein (no.37), ATPdependent (S)-NAD(P)H-hydrate dehydratase

Table 2

Oilseed rape blossom honey identified proteins: I-IV identified from SDS-PAGE and 1-28 identified from 2DE

\begin{tabular}{|c|c|c|c|c|c|c|c|c|}
\hline \multirow[b]{2}{*}{ Spot no. } & \multirow{2}{*}{$\begin{array}{c}\mathrm{AC} \\
\text { [accession } \\
\text { number] }\end{array}$} & \multirow{2}{*}{$\begin{array}{l}\text { Description of protein } \\
\text { [protein name, origin] }\end{array}$} & \multirow{2}{*}{$\begin{array}{c}\text { Matching } \\
\text { [sequence } \\
\text { coverage } \\
\% \text { ] }\end{array}$} & \multicolumn{2}{|c|}{ Theoretical } & \multicolumn{2}{|c|}{ Experimental } & \multirow{2}{*}{$\begin{array}{l}\text { Protein } \\
\text { Score } \\
\text { C.I. \% }\end{array}$} \\
\hline & & & & $\begin{array}{l}M w, \\
\mathrm{kDa}\end{array}$ & $\begin{array}{l}\mathrm{pl}, \\
\mathrm{pH}\end{array}$ & $\begin{array}{l}\text { Mw, } \\
\mathrm{kDa}\end{array}$ & $\begin{array}{l}\mathrm{pl}_{1} \\
\mathrm{pH}\end{array}$ & \\
\hline I & Q17058 & $\begin{array}{c}\text { Alpha-glucosidase OS=Apis } \\
\text { mellifera }\end{array}$ & 46 & 65.5 & 5.06 & $67-71$ & - & 100 \\
\hline la & Q17060 & $\begin{array}{c}\text { Major royal jelly protein } 3 \text { OS=Apis } \\
\text { mellifera }\end{array}$ & 28 & 61.6 & 6.47 & $62-68$ & - & 100 \\
\hline$\|$ & 018330 & $\begin{array}{l}\text { Major royal jelly protein } 1 \text { OS=Apis } \\
\text { mellifera }\end{array}$ & 57 & 48.8 & 5.1 & $50-55$ & - & 100 \\
\hline III & 077061 & $\begin{array}{l}\text { Major royal jelly protein } 2 \text { OS=Apis } \\
\text { mellifera }\end{array}$ & 39 & 51 & 6.83 & $47-51$ & - & 100 \\
\hline IV & 077061 & $\begin{array}{c}\text { Major royal jelly protein } 2 \text { OS=Apis } \\
\text { mellifera }\end{array}$ & 36 & 51 & 6.83 & $47-51$ & - & 100 \\
\hline IVa & 097432 & $\begin{array}{l}\text { Major royal jelly protein } 5 \text { OS=Apis } \\
\text { mellifera }\end{array}$ & 17 & 70 & 5.95 & $47-51$ & - & 99.96 \\
\hline $\begin{array}{l}\text { 1; 15a; 16b; } \\
\text { 17b; 18; } 19 ; \\
20 ; 21 ; 22 ; 23\end{array}$ & 018330 & $\begin{array}{l}\text { Major royal jelly protein } 1 \text { OS=Apis } \\
\text { mellifera }\end{array}$ & $35-48$ & 4.8 & 5.1 & 53.6 & 4.7 & 100 \\
\hline 2 & Q9Y823 & $\begin{array}{c}\text { Homocitrate synthase, mitochon- } \\
\text { drial OS=Schizosaccharomyces } \\
\text { pombe }\end{array}$ & 3 & 46.2 & 5.69 & 46.8 & 4.9 & 0 \\
\hline $\begin{array}{c}\text { 3; 4; 5a; 6a; 9a; } \\
\text { 10c; 11b; 12b; } \\
\text { 13b; 15b; 16a; } \\
\text { 17a }\end{array}$ & Q17060 & $\begin{array}{c}\text { Major royal jelly protein } 3 \text { OS=Apis } \\
\text { mellifera }\end{array}$ & $23-27$ & 61.6 & 6.47 & 39.6 & 5.0 & 100 \\
\hline $\begin{array}{l}\text { 5b; 6c; 7b; 9b; } \\
\text { 10a; 13a; } 14\end{array}$ & 077061 & $\begin{array}{l}\text { Major royal jelly protein } 2 \text { OS=Apis } \\
\text { mellifera }\end{array}$ & 27-30 & 51.04 & 6.83 & 39.4 & 5.2 & 99.97 \\
\hline $\begin{array}{l}6 \mathrm{~b} ; 7 \mathrm{a} ; 10 \mathrm{~b} ; \\
11 \mathrm{a} ; 11 \mathrm{c} ; 12 \mathrm{c}\end{array}$ & 097432 & $\begin{array}{l}\text { Major royal jelly protein } 5 \text { OS=Apis } \\
\text { mellifera }\end{array}$ & 31-35 & 70.1 & 5.95 & 39.5 & 5.3 & 100 \\
\hline 8 & 094657 & $\begin{array}{c}\text { Dnal protein homolog xdj1 } \\
\text { OS=Schizosaccharomyces pombe }\end{array}$ & 22 & 46.09 & 5.83 & 40.0 & 5.6 & 0 \\
\hline $\begin{array}{l}24 ; 25 ; 26 ; 27 ; \\
28\end{array}$ & Q17058 & $\begin{array}{c}\text { Alpha-glucosidase OS=Apis } \\
\text { mellifera }\end{array}$ & $33-45$ & 65.5 & 5.06 & $71-75$ & 4.9-9.8 & 89-100 \\
\hline
\end{tabular}


Table 3

Proteins identified from Brassica napus honey using gel-free mass spectrometry analysis. BRANABrassica napus origin, APIME- honeybee origin

\begin{tabular}{|c|c|c|c|c|c|c|c|}
\hline \multirow{2}{*}{ Protein description } & \multirow{2}{*}{ Entry } & \multicolumn{2}{|c|}{$\begin{array}{l}\text { Hand-collected } \\
\text { pollen }\end{array}$} & \multicolumn{2}{|c|}{$\begin{array}{l}\text { Bee-collected } \\
\text { pollen }\end{array}$} & \multicolumn{2}{|c|}{ Honey } \\
\hline & & $\begin{array}{c}\text { Coverage } \\
(\%)\end{array}$ & $\begin{array}{l}\text { Amount } \\
\text { (fmol) }\end{array}$ & $\begin{array}{c}\text { Coverage } \\
(\%)\end{array}$ & $\begin{array}{l}\text { Amount } \\
(\mathrm{fmol})\end{array}$ & $\begin{array}{c}\text { Coverage } \\
(\%)\end{array}$ & $\begin{array}{c}\text { Amount } \\
(\mathrm{fmol})\end{array}$ \\
\hline \multicolumn{8}{|c|}{ Biological function: metabolic and biosynthesis process } \\
\hline Triosephosphate isomerase & $\begin{array}{l}\text { A0A078CJ83_ } \\
\text { BRANA }\end{array}$ & 71.2 & 8.05 & 71.6 & 7.5 & 38.5 & 3.9 \\
\hline BnaA03g06790D & $\begin{array}{l}\text { AOA078CPV5_ } \\
\text { BRANA }\end{array}$ & 72.2 & 43.8 & 75.8 & 37.3 & 50.9 & 5.5 \\
\hline BnaA06g31290D & $\begin{array}{l}\text { A0A078DBI5_ } \\
\text { BRANA }\end{array}$ & 56.5 & 35.5 & 56.5 & 35.5 & 16.9 & 2.9 \\
\hline Malic enzyme & $\begin{array}{l}\text { A0A078DLS5_ } \\
\text { BRANA }\end{array}$ & & & & & 22.9 & 1.2 \\
\hline $\begin{array}{l}\text { Glyceraldehyde } 3 \text { phosphate } \\
\text { dehydrogenase }\end{array}$ & $\begin{array}{l}\text { AOA078IJWO_ } \\
\text { BRANA }\end{array}$ & 85.1 & 31.9 & 85.1 & 7.9 & 55.6 & 12.3 \\
\hline $\begin{array}{l}\text { Fructose bisphosphate } \\
\text { aldolase }\end{array}$ & $\begin{array}{l}\text { AOA078JFE6_ } \\
\text { BRANA }\end{array}$ & 88.2 & 26.3 & 88.2 & 26.2 & 10.8 & 1.4 \\
\hline Glucosylceramidase & $\begin{array}{l}\text { A0A088APM5_ } \\
\text { APIME }\end{array}$ & & & & & 42.2 & 15.6 \\
\hline BnaC02g07610D & $\begin{array}{l}\text { AOA078EPU3_- } \\
\text { BRANA }\end{array}$ & 67.4 & 25.1 & 69.9 & 24.5 & 45.2 & 4.9 \\
\hline BnaC02g38360D & $\begin{array}{l}\text { AOA078EWU2 } \\
\text { BRANA }\end{array}$ & 65.4 & 71.9 & 59.1 & 71.9 & 16.1 & 1.0 \\
\hline BnaC04g36920D & $\begin{array}{l}\text { AOA078G4E6_- } \\
\text { BRANA }\end{array}$ & 48.9 & 21 & 48.9 & 21 & 38 & 1.2 \\
\hline BnaC01g39610D & $\begin{array}{l}\text { A0A078G6P5 } \\
\text { BRANA }\end{array}$ & 67.7 & 80.3 & 67.7 & 80.3 & 59.9 & 27.6 \\
\hline Malate dehydrogenase & $\begin{array}{l}\text { A0A078GG36_ } \\
\text { BRANA }\end{array}$ & 70.8 & 9.1 & 70.8 & 12.2 & 56.4 & 1.5 \\
\hline Alcohol dehydrogenase 1 & $\begin{array}{l}\text { ADH1 }_{-} \\
\text {YEAST }\end{array}$ & 46.5 & 25 & 46.5 & 25 & 34.1 & 25 \\
\hline Alpha glucosidase & $\begin{array}{l}\text { Q25BT6_ } \\
\text { APIME }\end{array}$ & & & & & 78.3 & 17.5 \\
\hline Polygalacturonase & $\begin{array}{l}\text { Q7Y1T6_- } \\
\text { BRANA }\end{array}$ & 68 & 53.2 & 68 & 53.2 & 53.1 & 13.8 \\
\hline Alpha amylase & $\begin{array}{l}\text { Q9U8X5 } \\
\text { APIME }\end{array}$ & & & & & 73 & 18.4 \\
\hline Nucleoside diphosphate kinase & $\begin{array}{l}\text { A0A078HV31_ } \\
\text { BRANA }\end{array}$ & 74.3 & 18.9 & 74.3 & 15.7 & 13.5 & 2.2 \\
\hline \multicolumn{8}{|c|}{ Biological function: lipid/ion transport } \\
\hline Non specific lipid transfer & $\begin{array}{l}\text { AOA078I7R0_ } \\
\text { BRANA }\end{array}$ & 49.1 & 5.5 & 49.1 & 5.5 & 49.1 & 24.9 \\
\hline Transferrin & $\begin{array}{l}\text { AOA088AFH7_ } \\
\text { APIME }\end{array}$ & & & & & 46.3 & 0 \\
\hline
\end{tabular}

(no. 46), Chlorophyllase-2 (no. 50), Probable fructokinase-1 (no. 51), Chaperonin CPN60 (no. 87) and DNA-directed RNA polymerase subunit alpha (no. 103) exceeded the protein level by three times in hand-collected (Fig. 2, G1) oilseed rape pollen than in bee-collected. Only a few proteins with those quantitative changes observable and overexpressed in bee-collected oilseed rape pollen were detected, i.e. UDP-arabinopyranose mutase (no. 55), Mediator of RNA polymerase II transcription (no. 90), 5-methyltetrahydropteroyltriglutamate-homocysteine methyltransferase (no. 95, 96).

Detected proteins were described and divided 


\section{Rape pollen and honey proteomic analysis}

into a few groups according to their biological functions presented in Figure 2B. We found these transcription factors ( $6 \%$ of total identified proteins): probable WRKY transcription factor (Q9SUP6), protein SHI RELATED (Q9LQZ5) and a few Auxin-responsive proteins (Q38829, P49680). Another large group of detected proteins (68\% of total identified proteins) in 2DE gels were involved in metabolic processes and biosynthesis: Ferredoxin (P00221), UDPglucuronic acid decarboxylase (Q9SN95), fructokinase-1 (Q9SID0), 3-ketoacyl-CoA thiolase 2 (Q56WD9) and others listed in Table 1. The other identified proteins were important for ATP binding (33\% of total identified proteins), transcription processes (3\%), cytoskeleton/cell wall formation (19\%), etc.

\section{Protein profile from oilseed rape blossom honey}

Proteins from oilseed rape blossom honey were separated by SDS-PAGE or 2DE on $\mathrm{pH}$ 3-11 IPG strips and stained with CCB for visualization (Fig. 3). Approximately four to five protein bands were seen on SDS-PAGE gel and were all excised and subjected to in-gel tryptic digestion and identification by mass spectrometry analysis (MALDI-TOF-MS) and plant/bee protein database searching. We identified only proteins of bee origin: major royal jelly proteins and galactosidase (Tab. 2, I-IV). 2DE map (Fig. 3) showed similar results. 28 protein spots were excised and subjected to in-gel tryptic digestion. The positions of all proteins identified on 2DE gels were within the expected range of their theoretical isoelectric points and molecular sizes. From the 2DE gels we identified only proteins of bee origin: major royal jelly proteins 1-5 and galactosidase (Tab. 2, no. 1-28).

Protein profile comparison from hand- or beecollected pollen and oilseed rape blossom honey by gel-free analysis

Since we did not identify plant origin proteins in the honey samples, further the soluble proteins extracted from oilseed rape blossom honey, hand-collected oilseed rape pollen and bee-collected oilseed rape pollen were analyzed by direct gel-free mass spectrometry analysis using HDMS Synapt G2 mass spectrometer.

All identified proteins from the gel-free samples are listed in Supplement 2. Table 3 contains the list of proteins that were identified in honey samples of Brassica napus origin and honeybee origin. They were divided into three groups based on their biological function: metabolic/ biosynthesis, lipid/ion transport and unknown function.

\section{DISCUSSION}

The goal of this study was to characterize proteins in rape seed (Brassica napus L.) pollen and honey and to find proteins of plant origin that would help to characterize the honey. Few studies had dealt with the proteome of honey or pollen collected from different plants, but in 2012 F. Girolamo reported about seven proteins that were constituents in every type of honey. All seven proteins were of animal origin ( $A$. mellifera) except one glyceraldehyde-3-phosphate dehydrogenase from Mesembryanthemum crystallinum, which was found, apparently accidentally, in only one honey variety, and no additional proteins being attributed to plants, e.g. in pollen, nectar (Girolamo, D'Amato, \& Righetti, 2012).

Since hand-collected and bee-collected pollen can differ in chemical properties, e.g. vitamin content, we decided to compare proteomic 2DE maps and find the differences. All identified proteins were divided into groups depending on their function in the plant cell. A separate group of identified proteins are transcription factors. We observed that these proteins were more expressed in hand-collected pollen samples, especially Auxin-responsive protein IAA11, which were involved in many aspects of plant growth and development and long known to control diverse responses to external stimuli (Chandler, 2016). Another transcription factor, the protein SHI RELATED, bound DNA on 5'-ACTCTAC-3' and promoted auxin homeostasis-regulating gene expression, e.g. YUC genes, as well as genes affecting stamen development, cell expansion and timing of flowering (Hong et al., 2012). In 
a recent study, we had performed proteomic analysis of red, berseem and white clover pollen (Treigytè et al., 2014) and detected over 30 protein spots whose quantitative levels were most divergent in investigated clover pollen.

In rape seed we also identified PHD finger protein ALFIN-LIKE 4 protein (Supplement 1) which could be involved inchromatin remodeling and protein RALF-like 16 (Supplement 1) which could be important in cell-cell signaling as was suggested by Kayum et al. (2015). In our study, we reported that SDS-PAGE or 2DE separation of rape seed blossom honey proteins could not represent all protein content. Only major royal jelly proteins and galactosidase of bee origin were detected and no plant proteins during gel-based analysis.

We carried out a gel-free analysis of rape seed pollen (hand- or bee-collected) and rape seed honey. We observed around twenty different plant (rape seed) proteins in the honey sample and all were involved in metabolic or biosynthesis processes like Tiosephosphate isomerase, Malic enzyme and Malate dehydrogenase. We also detected all major jelly proteins (1-9) from honeybees in the honey sample. The major royal jelly proteins (MRJPs) comprised $12.5 \%$ of the mass and $82-90 \%$ of the protein content of honeybee (Apis mellifera) royal jelly (Girolamo, D’Amato, \& Righetti, 2012). Royal jelly is a substance secreted by the cephalic glands of nurse bees and is used to trigger the development of a queen bee from a bee larva. The biological function of the MRJPs is unknown, but they are believed to play a major role in nutrition due to their high essential amino acid content (Bhattacharya et al., 1999). Two royal jelly proteins, MRJP3 and MRJP5, contain a tandem repeat that results from a high genetic variability. This polymorphism may be useful for genotyping individual bees. We suggest that all identified proteins can be used for further investigation to find biological markers for honey of different origin types.

Conflict of Interest: The authors declare that they have no conflict of interest.

\section{ACKNOWLEDGEMENTS}

This research was funded by a grant (No. SVE-01/2012) from the Research Council of Lithuania. The authors thank Dr. Mindaugas Valius, Dr. Algirdas Kaupinis and Dr. Marija Ger for their excellent assistance in mass spectrometry.

\section{REFERENCES}

Al-Mamary, M., Al-Meeri, A., \& Al-Habori, M. (2002). Antioxidant activities and total phenolics of different types of honey. Nutrition Research, 22(9), 1041-1047. DOl: 10.1016/S0271-5317(02)004062

Babizhayev, M.A., Vishnyakova, K.S., \& Yegorov, Y.E. (2014). Oxidative damage impact on aging and age-related diseases: drug targeting of telomere attrition and dynamic telomerase activity flirting with imidazole-containing dipeptides. Recent Patents on Drug Delivery \& Formulation, 8(3), 163192. DOl: 10.2174/18722113086661406021255 05

Bhattacharya, D., Klaudiny, J., Schmitzová, J., Simúth, J. (1999). The family of major royal jelly proteins and its evolution. The Journal of Molecular Evolution, 49(2), 290-297. D0l: 10.1242/bio.20147211

Bookstein, F.L. (1989). Principal warps: thin plate splines and the decomposition of deformations. IEEE Transactions on Pattern Analysis Machine Intelligence, 11(6), 567-585. DOl: 10.1109/34.24792

Brudzynski, K., \& Kim, L. (2011). Storage-induced chemical changes in active components of honey de-regulate its antibacterial activity. Food Chemistry, 126(3), 1155-1163. D0l:10.1016/j.foodchem.2010.11.151

Cai, T., Wagenlehner, F.M.E., Luciani, L.G., Tiscione, D., Malossini, G., Verze, P., Mirone, V., Bartoletti, R. (2014). Pollen extract in association with vitamins provides early pain relief in patients affected by chronic prostatitis/chronic pelvic pain sindrome. Experimental and Therapeutic Medicine, 8, 1032- 


\section{BORUTINSKHIIIE Et HL. _ Rape pollen and honey proteomic analysis}

1038. DOl: $10.3892 /$ etm.2014.1861

Chandler J.W. (2016). Auxin response factors. Plant Cell Environment, 39(5), 1014-1028. DOl: 10.1111/pce.12662

Chardin, H., Mayer, C., Sénéchal, H., Tepfer, M., DesvauX, F.X., Peltre, G. (2001). Characterization of high-molecular-mass allergens in oilseed rape pollen. International Archives of Allergy and Immunology, 125(2), 128-134. DOl:10.1159/000053806

Dowsey, A.W., English, J.A., Lisacek, F., Morris, J.S., Yang, G.Z., Dunn, M.J. (2010). Image analysis tools and emerging algorithms for expression proteomics. Proteomics, 10, 4226-4257. DOl: 10.1002/pmic.200900635

Erejuwa, O.O., Sulaiman, S.A., \& Wahab, M.S. (2012). Honey: a novel antioxidant. Molecules, 174), 4400-4423. DOl: 10.3390/molecules 17044400

Erlund, I. (2004). Review of the flavonoids quercetin, hesperetin, and naringenin. Dietary sources, bioactivities, bioavailability, and epidemiology. Nutrition Research, 24(10), 851-874. DOl: http://dx.doi.org/10.1016/j.nutres.2004.07.005

Ferreira, I., Aires, E., Barreira, J.C.M., Estevinho, L.M. (2009). Antioxidant activity of Portuguese honey samples: different contributions of the entire honey and phenolic extract. Food Chemistry, 714(4), 1438-1443. DOl: 10.1016/j. foodchem.2008.11.028

Focke, M., Hemmer, W., Valenta, R., Götz, M., Jarisch, R. (2003). Identification of oilseed rape (Brassica napus) pollen profilin as a crossreactive allergen. International Archives of Allergy and Immunology, 132(2), 116-123. DOl: 10.1159/000073712

Girolamo, F., D'Amato, A., \& Righetti, P.G. (2012). Assessment of the floral origin of honey via proteomic tools. Journal of Proteomics, 75(12),
3688-3693. DOl: 10.1016/j.jprot.2012.04.029

Gracham, J.M. (1992). The Hive and the Honey Bee. Dadant \& Sons

Gulden, R.H., Warwick, S.l., \& Thomas, A.G. (2008). The biology of Canadian weeds. 137. Brassica napus L. and B. rapa L Can. Journal of Plant Science, 88, 951-996. D0l: 10.4141/ CJPS07203

Hong, J.K., Kim, J.A., Kim, J.S., Lee, S.I, Koo, B.S., Lee, Y.H. (2012). Overexpression of Brassica rapa SHI-RELATED SEQUENCE genes suppresses growth and development in Arabidopsis thaliana. Biotechmology Letters, 34, 1561-1569. DOl: 10.1007/s10529-012-09290

Islam, R., Polash, A.H., Sakib, M.S., Saha, Ch., Rahman, A. (2013). Computational identification of Brassica napus pollen specific protein Bnml as an allergen. International Journal on Bioinformatics \& Biosciences, 3(2), 43-55. DOl: 10.5121/ijbb.2013.3205

Jiang, T., Sun, Q., \& Chen, S. (2016). Oxidative stress: A major pathogenesis and potential therapeutic target of antioxidative agents in Parkinson's disease and Alzheimer's disease. Progress in Neurobiology, 147,1-19. DOl: 10.1016/j.pneurobio.2016.07.005

Kayum, A., Park, J., Ahmed, N.U., Jung, H.J., Saha, G., Kang, J.K., Nou, I.S. (2015). Characterization and stress-induced expression analysis of Alfin-like transcription factors in Brassica rapa. Molecular Genetics and Genomics, 290, 1299-1311. DOI: 10.1007/s00438-0150993-y

Nasir, N.M., Halim, A.S., Singh, K.B., Dorai, A.A., Haneef, M.M. (2010). Antibacterial properties of tualang honey and its effect in burn wound management: a comparative study. BMC Complementary and Alternative Medicine, 10, 31. DOl: 10.1155/2013/313798 
Poikonen, S., Kotovuori, A., Kalkkinen, N., Vaali, K., Reunala, T., Turjanmaa, K., Palosuo, T. (2006). Napins, 2S albumins, are major allergens in oilseed rape and turnip rape. Journal of allergy and clinical immunology, 7172), 426-432. DOl: 10.1016/j. jaci.2005.10.004

Serackis, A., \& Navakauskas, D. (2010). Treatment of over-saturated protein spots in two-dimensional electrophoresis gel images. Informatica, 27(3), 409-424 WOS:000283389700008

Sheoran, I.S., Ross, A.R., Olson, D.J., Sawhney, V.K. (2007). Proteomic analysis of tomato (Lycopersicon esculentum) pollen. Journal of Experimental Botany, 58, 3525-3535. DOl: 10.1093/jxb/ erm199

Shevchenko, A., Wilm, M., Vorm, O., Mann, M. (1996). Mass spectrometric sequencing of proteins silver-stained polyacrylamide gels. AnaIytical Chemistry, 68, 850-858. D0l: 10.1021/ ac950914h

da Silva, P.M., Gauche, C., Gonzaga, L.V., Costa, A.C., Fett, R. (2016). Honey: Chemical composition, stability and authenticity. Food Chemistry, 196, 309-323. DOl: 10.1016/j.foodchem.2015.09.051

Tonks, A.l., Cooper, R.A., Jones, K.P., Blair, S., Parton, J., Tonks, A. (2003). Honey stimulates inflammatory cytokine production from monocytes. Cytokine, 27(5), 242-247. DOl: 10.1016/S10434666(03)00092-9

Treigytè, G., Zaikova, I., Matuzevičius, D., Čeksterytè, V., Dabkevičienè, G., Kurtinaitienè, B., Navakauskiené, R. (2014). Comparative proteomic analysis of pollen of Trifolium pratense, T. alexandrinumand T.repens. Zemdirbyste-Agriculture, 101(4), 453-460 WOS:000348823900015

Valledor, L., \& Jorrín, J. (2011). Back to the basics: maximizing the information obtained by quantitative two dimensional gel electrophoresis analyses by an appropriate experimental design and statistical analyses. Journal of proteomics, 74(1), 1-18. DOl: 10.1016/j.jprot.2010.07.007
Wagenlehner, F.M., Schneider, H., Ludwig, M., Schnitker, J., Brähler, E., Weidner, W. (2009). A pollen extract (Cernilton) in patients with inflammatory chronic prostatitis-chronic pelvic pain syndrome: a multicentre, randomised, prospective, double-blind, placebo-controlled phase 3 study. European Urology, 56(3), 544-551. DOl: 10.1016/j.eururo.2009.05.046

Wisniewski, J.R., Zougman, A., Nagaraj, N., Mann, M. (2009). Universal sample preparationmethod for proteome analysis. Nature Methods, 6, 359362. D01:10.1038/nmeth.1322 


\section{SUPPLEMENT 1}

\begin{tabular}{|c|c|c|c|c|c|c|c|c|c|c|c|}
\hline \multirow{2}{*}{$\mathrm{Nr}}$. & \multirow{2}{*}{$\begin{array}{c}A C \\
\text { [accession } \\
\text { number] }\end{array}$} & \multirow{2}{*}{ Entry } & \multirow{2}{*}{ Description of protein [protein name] } & \multirow{2}{*}{ 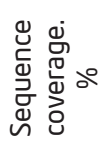 } & \multirow{2}{*}{ 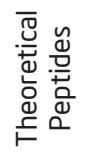 } & \multirow{2}{*}{ 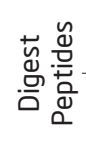 } & \multicolumn{2}{|c|}{ Theor. } & \multicolumn{2}{|c|}{ Exp. } & \multirow{2}{*}{$\begin{array}{c}\begin{array}{c}\text { Fold } \\
\text { change }\end{array} \\
\text { G1/G2 }\end{array}$} \\
\hline & & & & & & & $\begin{array}{l}\text { Mw, } \\
\mathrm{kDa}\end{array}$ & $\mathrm{pl}$ & $\begin{array}{l}\text { Mw, } \\
\text { kDa }\end{array}$ & $\mathrm{pl}, \mathrm{pH}$ & \\
\hline 1 & P00221 & FER1_SPIOL & Ferredoxin-1, chloroplastic OS=Spinacia oleracea & 27.3 & 11 & 3 & 15.64 & 4.33 & 13.4 & 5.9 & 2.2 \\
\hline 2 & Q0J9V6 & Y4294_ORYS] & $\begin{array}{c}\text { Uncharacterized protein Os04g0629400 } \\
\text { OS=0ryza sativa subsp. japonica }\end{array}$ & 42.9 & 7 & 3 & 12.04 & 6.69 & 10.9 & 6.2 & 2.3 \\
\hline 3 & A1EA43 & IF1C_AGRST & $\begin{array}{l}\text { Translation initiation factor IF-1, chloroplastic } \\
\text { OS }=\text { Agrostis stolonifera }\end{array}$ & 7.7 & 26 & 2 & 12.45 & 9.52 & 12.2 & 8.4 & 3.6 \\
\hline 4 & Q0G9T9 & RK20_DAUCA & $\begin{array}{c}50 \text { S ribosomal protein L20, chloroplastic } \\
\text { OS=Daucus carota }\end{array}$ & 9.4 & 32 & 3 & 15.24 & 11.81 & 12 & 9.5 & 1.7 \\
\hline 5 & P07924 & RT13_WHEAT & $\begin{array}{c}\text { Ribosomal protein S13, mitochondrial OS=Triticum } \\
\text { aestivum }\end{array}$ & 26.1 & 23 & 6 & 13.42 & 10.57 & 13.2 & 9.5 & 1.5 \\
\hline 6 & Q852K5 & SAP6_ORYS] & $\begin{array}{c}\text { Zinc finger A20 and AN1 domain-containing } \\
\text { stress-associated protein } 6 \text { OS=Oryza sativa } \\
\text { subsp. japonica }\end{array}$ & 15.4 & 26 & 4 & 17.52 & 8.9 & 14.4 & 9.4 & 2.9 \\
\hline 7 & Q9FZP6 & MBD12_ARATH & $\begin{array}{l}\text { Putative methyl-CpG-binding domain protein } 12 \\
\text { OS=Arabidopsis thaliana }\end{array}$ & 16.7 & 24 & 4 & 17.87 & 9.41 & 15.9 & 9.4 & 1.1 \\
\hline 8 & P42794 & RL112_ARATH & $\begin{array}{c}\text { 60S ribosomal protein L11-2 OS=Arabidopsis } \\
\text { thaliana }\end{array}$ & 11.4 & 35 & 4 & 20.84 & 9.94 & 17.3 & 9.3 & 3.3 \\
\hline 9 & P51427 & RS52_ARATH & $\begin{array}{c}\text { 40S ribosomal protein } \mathrm{S} 5-2 \text { OS=Arabidopsis } \\
\text { thaliana }\end{array}$ & 10.0 & 30 & 3 & 22.90 & 9.66 & 19.1 & 9.2 & 2.8 \\
\hline 10 & Q9C505 & IF5A3_ARATH & $\begin{array}{l}\text { Eukaryotic translation initiation factor } 5 \mathrm{~A}-3 \\
\text { OS=Arabidopsis thaliana }\end{array}$ & 16.7 & 18 & 3 & 17.19 & 5.56 & 15.7 & 5.4 & 2.3 \\
\hline 11 & Q9LR33 & R27A2_ARATH & $\begin{array}{c}60 S \text { ribosomal protein L27a-2 OS=Arabidopsis } \\
\text { thaliana }\end{array}$ & 9.4 & 32 & 3 & 16.28 & 10.5 & 16 & 4.5 & 1.2 \\
\hline 12 & Q40089 & ATP4_IPOBA & $\begin{array}{c}\text { ATP synthase subunit delta', mitochondrial } \\
\text { OS=lpomoea batatas }\end{array}$ & 22.2 & 18 & 4 & 21.30 & 5.93 & 17 & 4.8 & 2.4 \\
\hline 13 & P43349 & TCTP_SOLTU & $\begin{array}{l}\text { Translationally-controlled tumor protein homolog } \\
\text { OS=Solanum tuberosum }\end{array}$ & 21.1 & 19 & 4 & 18.83 & 4.58 & 18.1 & 4.5 & 3.0 \\
\hline 14 & Q68S00 & ATPE_PANGI & $\begin{array}{l}\text { ATP synthase epsilon chain, chloroplastic } \\
\text { OS=Panax ginseng }\end{array}$ & 12.5 & 16 & 2 & 15.36 & 5.25 & 15.6 & 5.9 & 2.8 \\
\hline 15 & P81766 & NDK3_SPIOL & $\begin{array}{c}\text { Nucleoside diphosphate kinase } 3 \text { OS=Spinacia } \\
\text { oleracea }\end{array}$ & 13.6 & 22 & 3 & 17.10 & 8.12 & 14 & 6.8 & 1.6 \\
\hline 16 & P24525 & CYPH_BRANA & $\begin{array}{c}\text { Peptidyl-prolyl cis-trans isomerase OS=Brassica } \\
\text { napus }\end{array}$ & 30.4 & 23 & 7 & 18.50 & 8.57 & 15.5 & 7.3 & 1.6 \\
\hline 17 & Q04613 & MI25_ARATH & $\begin{array}{c}\text { ATP synthase protein MI25 OS=Arabidopsis } \\
\text { thaliana }\end{array}$ & 18.5 & 27 & 5 & 21.67 & 9.53 & 16.1 & 8.1 & 1.0 \\
\hline 18 & P93224 & NLTP2_SOLLC & $\begin{array}{c}\text { Non-specific lipid-transfer protein } 2 \text { OS=Solanum } \\
\text { lycopersicum }\end{array}$ & 36.4 & 11 & 4 & 11.47 & 8.04 & 13.9 & 7.5 & 1.3 \\
\hline 19 & P29110 & OLEO3_BRANA & Oleosin Bn-III OS=Brassica napus & 17.4 & 23 & 4 & 21.52 & 9.3 & 16.5 & 7.2 & -1.0 \\
\hline 20 & P34944 & NDUS3_MARPO & $\begin{array}{l}\text { NADH dehydrogenase [ubiquinone] iron-sulfur } \\
\text { protein } 3 \text { OS=Marchantia polymorpha }\end{array}$ & 12.5 & 24 & 3 & 23.33 & 6.21 & 17.9 & 8.3 & 3.4 \\
\hline 21 & P93000 & GL23_ARATH & $\begin{array}{c}\text { Germin-like protein subfamily } 2 \text { member } 3 \\
\text { OS=Arabidopsis thaliana }\end{array}$ & 5.6 & 18 & 1 & 23.01 & 8.85 & 17.7 & 6.7 & -1.1 \\
\hline 22 & QOZIYO & RR3_VITVI & $\begin{array}{c}\text { 30S ribosomal protein S3, chloroplastic OS=Vitis } \\
\text { vinifera }\end{array}$ & 15.4 & 39 & 6 & 25.22 & 9.97 & 18.2 & 7.2 & 1.1 \\
\hline 23 & P49208 & RK1_PEA & $\begin{array}{l}\text { 50S ribosomal protein L1, chloroplastic (Fragment) } \\
\text { OS=Pisum sativum }\end{array}$ & 2.6 & 39 & 1 & 23.48 & 10.23 & 17.6 & 7 & 4.2 \\
\hline 24 & Q8GXZ3 & Y5102_ARATH & $\begin{array}{c}\text { Serine/threonine-protein kinase At5g01020 } \\
\text { OS=Arabidopsis thaliana }\end{array}$ & 1.9 & 53 & 1 & 45.58 & 9.21 & 19.9 & 7.8 & 1.9 \\
\hline 25 & Q9ZU31 & PP138_ARATH & $\begin{array}{l}\text { Pentatricopeptide repeat-containing protein } \\
\text { At2g01360 OS=Arabidopsis thaliana }\end{array}$ & 19.0 & 21 & 4 & 20.32 & 6.07 & 20 & 7 & 1.3 \\
\hline
\end{tabular}

04 


\begin{tabular}{|c|c|c|c|c|c|c|c|c|c|c|c|}
\hline 26 & P49680 & IAA6_PEA & Auxin-induced protein IAA6 OS=Pisum sativum & 6.3 & 32 & 2 & 20.31 & 6.74 & 20.7 & 4.7 & 1.0 \\
\hline 27 & 081488 & ALFL4_ARATH & $\begin{array}{c}\text { PHD finger protein ALFIN-LIKE } 4 \text { OS=Arabidopsis } \\
\text { thaliana }\end{array}$ & 11.1 & 36 & 4 & 28.76 & 5.01 & 22.4 & 4.2 & 1.3 \\
\hline 3 & P21216 & IPYR2_ARATH & $\begin{array}{c}\text { Soluble inorganic pyrophosphatase } 2 \\
\text { OS=Arabidopsis thaliana }\end{array}$ & 3.4 & 29 & 1 & 24.65 & 5.72 & 23.9 & 5 & 5.5 \\
\hline & Q9ZT49 & ATL45_ARATH & $\begin{array}{l}\text { RING-H2 finger protein ATL45 OS=Arabidopsis } \\
\text { thaliana }\end{array}$ & 15.8 & 19 & 3 & 21.06 & 7.01 & 21.7 & 5.4 & 2.2 \\
\hline & Q01197 & E6_GOSHI & Protein E6 OS=Gossypium hirsutum & 14.8 & 27 & 4 & 28.20 & 5.14 & 22.6 & 5.6 & 1.4 \\
\hline & P42748 & UBC4_ARATH & $\begin{array}{c}\text { Ubiquitin-conjugating enzyme E2 } 4 \\
\text { OS=Arabidopsis thaliana }\end{array}$ & 21.1 & 19 & 4 & 21.28 & 4.23 & 21.8 & 5.6 & 2.1 \\
\hline & 004905 & KCY_ARATH & UMP-CMP kinase OS=Arabidopsis thaliana & 13.3 & 30 & 4 & 22.46 & 5.79 & 21 & 5.6 & 2.5 \\
\hline & Q38829 & IAA11_ARATH & $\begin{array}{c}\text { Auxin-responsive protein IAA11 OS=Arabidopsis } \\
\text { thaliana }\end{array}$ & 13.8 & 29 & 4 & 26.49 & 5.82 & 22.9 & 5.8 & 9.2 \\
\hline & Q9FI61 & UBC27_ARATH & $\begin{array}{l}\text { Ubiquitin-conjugating enzyme E2 } 27 \\
\text { OS=Arabidopsis thaliana }\end{array}$ & 10.0 & 20 & 2 & 21.24 & 5 & 26.1 & 4.6 & -1.7 \\
\hline & Q75IR6 & ALFL1_ORYSJ & $\begin{array}{c}\text { PHD finger protein ALFIN-LIKE } 1 \text { OS=Oryza sativa } \\
\text { subsp. japonica }\end{array}$ & 13.5 & 37 & 5 & 28.85 & 5.52 & 29 & 4.4 & 2.9 \\
\hline 36 & Q9C5W6 & 14312_ARATH & $\begin{array}{c}\text { 14-3-3-like protein GF14 iota OS=Arabidopsis } \\
\text { thaliana }\end{array}$ & 20.6 & 34 & 7 & 30.52 & 4.83 & 29.4 & 4.7 & -1.5 \\
\hline 37 & Q39056 & CNX3_ARATH & $\begin{array}{c}\text { Cyclic pyranopterin monophosphate synthase } \\
\text { accessory protein, mitochondrial OS=Arabidopsis } \\
\text { thaliana }\end{array}$ & 16.7 & 36 & 6 & 29.49 & 8.22 & 18.6 & 6.3 & 6.3 \\
\hline & Q01197 & E6_GOSHI & Protein E6 OS=Gossypium hirsutum & 18.5 & 27 & 5 & 28.20 & 5.14 & 24 & 7.5 & 1.3 \\
\hline & Q10GP0 & Y3198_ORYS] & $\begin{array}{c}\text { Putative B3 domain-containing protein } \\
\text { Os03g0619850 OS=Oryza sativa subsp. japonica }\end{array}$ & 12.9 & 31 & 4 & 28.11 & 7.13 & 24.9 & 7.9 & 1.2 \\
\hline 0 & 036052 & RR4_PATSQ & $\begin{array}{c}\text { 30S ribosomal protein S4, chloroplastic } \\
\text { (Fragment) OS=Patersonia sp. (strain Lejeune } \\
\text { 1997) }\end{array}$ & 10.8 & 37 & 4 & 22.78 & 10.48 & 24.2 & 8.2 & 2.1 \\
\hline & 023609 & PER41_ARATH & Peroxidase 41 OS=Arabidopsis thaliana & 4.7 & 43 & 2 & 36.17 & 8.51 & 27.4 & 7.2 & 1.3 \\
\hline 42 & Q10GP0 & Y3198_ORYSJ & $\begin{array}{c}\text { Putative B3 domain-containing protein } \\
\text { Os03g0619850 OS=Oryza sativa subsp. japonica }\end{array}$ & 16.1 & 31 & 5 & 28.11 & 7.13 & 30 & 8.3 & 1.5 \\
\hline 43 & P83291 & NB5R2_ARATH & $\begin{array}{l}\mathrm{NADH} \text {-cytochrome b5 reductase-like protein } \\
\text { OS=Arabidopsis thaliana }\end{array}$ & 13.5 & 37 & 5 & 35.96 & 8.76 & 30 & 9 & 1.2 \\
\hline & Q84WM7 & PPME1_ARATH & Pectinesterase PPME1 OS=Arabidopsis thaliana & 18.9 & 37 & 7 & 39.11 & 8.74 & 32.2 & 9.3 & 1.3 \\
\hline 45 & Q9SN95 & UXS5_ARATH & $\begin{array}{l}\text { UDP-glucuronic acid decarboxylase } 5 \\
\text { OS=Arabidopsis thaliana }\end{array}$ & 11.4 & 44 & 5 & 38.36 & 7.1 & 36 & 6.9 & 1.0 \\
\hline 16 & F6HDM2 & NNRD_VITVI & $\begin{array}{l}\text { ATP-dependent (S)-NAD(P)H-hydrate dehydratase } \\
\text { OS=Vitis vinifera }\end{array}$ & 4.8 & 42 & 2 & 38.08 & 8.3 & 36.4 & 7.1 & 3.9 \\
\hline 47 & Q9FLA3 & FBD42_ARATH & $\begin{array}{l}\text { Putative FBD-associated F-box protein } \\
\text { At5g44940 OS=Arabidopsis thaliana }\end{array}$ & 12.5 & 48 & 6 & 44.07 & 8.52 & 34.1 & 7.1 & 1.9 \\
\hline 48 & Q9M0R4 & ATL37_ARATH & $\begin{array}{c}\text { Putative RING-H2 finger protein ATL37 } \\
\text { OS=Arabidopsis thaliana }\end{array}$ & 10.0 & 40 & 4 & 39.97 & 7.9 & 32.6 & 6.1 & -2.0 \\
\hline 49 & P60314 & RPOA_AMBTC & $\begin{array}{l}\text { DNA-directed RNA polymerase subunit alpha } \\
\text { OS=Amborella trichopoda }\end{array}$ & 13.0 & 46 & 6 & 38.39 & 7.61 & 34.3 & 5.8 & 2.9 \\
\hline 50 & Q9M7I7 & CLH2_ARATH & $\begin{array}{c}\text { Chlorophyllase-2, chloroplastic OS=Arabidopsis } \\
\text { thaliana }\end{array}$ & 15.2 & 33 & 5 & 34.88 & 6.5 & 29.8 & 5.5 & 3.6 \\
\hline 51 & Q9SID0 & SCRK1_ARATH & Probable fructokinase-1 OS=Arabidopsis thaliana & 15.8 & 38 & 6 & 35.25 & 5.31 & 32.9 & 5.2 & 3.7 \\
\hline 52 & Q9SRT9 & RGP1_ARATH & $\begin{array}{c}\text { UDP-arabinopyranose mutase } 1 \text { OS=Arabidopsis } \\
\text { thaliana }\end{array}$ & 28.2 & 39 & 11 & 40.60 & 5.61 & 35.2 & 5.3 & 2.1 \\
\hline 53 & 082662 & SUCB_ARATH & $\begin{array}{l}\text { Succinyl-CoA ligase [ADP-forming] subunit beta, } \\
\text { mitochondrial OS=Arabidopsis thaliana }\end{array}$ & 16.1 & 56 & 9 & 45.31 & 6.3 & 39.5 & 5.4 & 2.6 \\
\hline 54 & Q9FHJ2 & DRL34_ARATH & $\begin{array}{c}\text { Probable disease resistance protein At5g45440 } \\
\text { OS=Arabidopsis thaliana }\end{array}$ & 10.0 & 50 & 5 & 39.42 & 5.2 & 37.7 & 5.3 & 1.7 \\
\hline & Q9SRT9 & RGP1_ARATH & $\begin{array}{c}\text { UDP-arabinopyranose mutase } 1 \text { OS=Arabidopsis } \\
\text { thaliana }\end{array}$ & 25.6 & 39 & 10 & 40.60 & 5.61 & 42.6 & 5.3 & -6.0 \\
\hline & P53494 & ACT4_ARATH & Actin-4 OS=Arabidopsis thaliana & 28.2 & 39 & 11 & 41.75 & 5.37 & 41.7 & 5.1 & 1.4 \\
\hline
\end{tabular}




\begin{tabular}{|c|c|c|c|c|c|c|c|c|c|c|c|}
\hline 57 & Q9SUP6 & $\begin{array}{l}\text { WRK53_- } \\
\text { ARATH }\end{array}$ & $\begin{array}{c}\text { Probable WRKY transcription factor } 53 \\
\text { OS=Arabidopsis thaliana }\end{array}$ & 10.3 & 39 & 4 & 36.25 & 6.34 & 42.1 & 5 & 1.9 \\
\hline 58 & P42748 & UBC4_ARATH & $\begin{array}{l}\text { Ubiquitin-conjugating enzyme E2 } 4 \\
\text { OS=Arabidopsis thaliana }\end{array}$ & 21.1 & 19 & 4 & 21.28 & 4.23 & 38.3 & 4.9 & 1.2 \\
\hline 59 & Q4PT02 & GAOX5_ARATH & $G N=G A 200 \times 5 P E=2 S V=1$ & 8.9 & 45 & 4 & 43.13 & 8.04 & 34.2 & 4.8 & -1.0 \\
\hline 60 & Q9М6АЗ & ASC1_SOLLC & Protein ASC1 OS=Solanum Iycopersicum & 2.8 & 36 & 1 & 36.27 & 7.66 & 44 & 5.5 & 1.3 \\
\hline 61 & Q9SMT9 & FBD9_ARATH & $\begin{array}{l}\text { FBD-associated F-box protein At3g49020 } \\
\text { OS=Arabidopsis thaliana }\end{array}$ & 3.8 & 52 & 2 & 51.38 & 5.71 & 44.4 & 4.6 & 2.2 \\
\hline 62 & Q9SJA6 & RZ22A_ARATH & $\begin{array}{l}\text { Serine/arginine-rich splicing factor RSZ22A } \\
\text { OS=Arabidopsis thaliana }\end{array}$ & 6.5 & 46 & 3 & 21.90 & 11.34 & 47.7 & 4.8 & 1.1 \\
\hline 63 & P53496 & ACT11_ARATH & Actin-11 OS=Arabidopsis thaliana & 5.3 & 38 & 2 & 41.64 & 5.23 & 48.6 & 5 & -1.8 \\
\hline 4 & Q9SJL8 & METK3_ARATH & $\begin{array}{l}\text { S-adenosylmethionine synthase } 3 \text { OS=Arabidopsis } \\
\text { thaliana }\end{array}$ & 2.2 & 45 & 1 & 42.47 & 5.76 & 46.2 & 5.6 & -1.1 \\
\hline 65 & Q9M1D3 & CISY5_ARATH & $\begin{array}{c}\text { Citrate synthase } 5 \text {, mitochondrial OS=Arabidopsis } \\
\text { thaliana }\end{array}$ & 17.0 & 47 & 8 & 51.69 & 6.2 & 45.1 & 5.7 & 1.4 \\
\hline 66 & Q9LQZ5 & SRS5_ARATH & $\begin{array}{c}\text { Protein SHI RELATED SEQUENCE } 5 \\
\text { OS=Arabidopsis thaliana }\end{array}$ & 12.5 & 32 & 4 & 38.53 & 6.67 & 46.9 & 5.8 & 2.4 \\
\hline 67 & Р35337 & PGLR_BRANA & Polygalacturonase OS=Brassica napus & 22.0 & 41 & 9 & 42.42 & 6.34 & 45.6 & 5.9 & -1.3 \\
\hline 68 & Q39980 & VTSS3_HYOMU & $\begin{array}{c}\text { Vetispiradiene synthase } 3 \text { (Fragment) } \\
\text { OS=Hyoscyamus muticus }\end{array}$ & 14.0 & 43 & 6 & 41.07 & 5.01 & 43.5 & 6.2 & 1.1 \\
\hline 69 & Р35337 & PGLR_BRANA & Polygalacturonase OS=Brassica napus & 24.4 & 41 & 10 & 42.42 & 6.34 & 43.4 & 6.5 & 1.2 \\
\hline 70 & Q56WD9 & THIK2_ARATH & $\begin{array}{c}\text { 3-ketoacyl-CoA thiolase 2, peroxisomal } \\
\text { OS=Arabidopsis thaliana }\end{array}$ & 11.1 & 54 & 6 & 48.54 & 8.62 & 42.4 & 7.1 & 2.8 \\
\hline 71 & Q56WD9 & THIK2_ARATH & $\begin{array}{l}\text { 3-ketoacyl-CoA thiolase 2, peroxisomal } \\
\text { OS=Arabidopsis thaliana }\end{array}$ & 9.3 & 54 & 5 & 48.54 & 8.62 & 43.6 & 6.9 & 2.3 \\
\hline 72 & Q56WD10 & THIK2_ARATH & $\begin{array}{l}\text { 3-ketoacyl-CoA thiolase 2, peroxisomal } \\
\text { OS=Arabidopsis thaliana }\end{array}$ & 13.0 & 54 & 7 & 48.54 & 8.62 & 44.6 & 6.8 & -1.1 \\
\hline 73 & Q9LSC2 & Y3589_ARATH & $\begin{array}{l}\text { PTI1-like tyrosine-protein kinase At3g15890 } \\
\text { OS=Arabidopsis thaliana }\end{array}$ & 2.2 & 45 & 1 & 40.92 & 5.36 & 41.1 & 6.8 & 1.3 \\
\hline 74 & Q8LFV3 & CDF3_ARATH & Cyclic dof factor 3 OS=Arabidopsis thaliana & 13.5 & 52 & 7 & 49.69 & 6.61 & 46.6 & 8 & 1.1 \\
\hline 75 & 023254 & GLYC4_ARATH & $\begin{array}{c}\text { Serine hydroxymethyltransferase } 4 \\
\text { OS=Arabidopsis thaliana }\end{array}$ & 15.1 & 53 & 8 & 51.68 & 6.8 & 51.4 & 6.7 & -1.1 \\
\hline 76 & 023254 & GLYC4_ARATH & $\begin{array}{c}\text { Serine hydroxymethyltransferase } 4 \\
\text { OS=Arabidopsis thaliana }\end{array}$ & 15.1 & 53 & 8 & 51.68 & 6.8 & 51.5 & 6.5 & -1.2 \\
\hline 77 & Р32290 & CATA_VIGRR & Catalase OS=Vigna radiata var. radiata & 1.7 & 59 & 1 & 56.80 & 6.79 & 52 & 6.1 & 1.4 \\
\hline 78 & P22201 & ATPAM_BRANA & $\begin{array}{l}\text { ATP synthase subunit alpha, mitochondrial } \\
\text { OS=Brassica napus }\end{array}$ & 12.3 & 57 & 7 & 55.10 & 6.23 & 56.2 & 5.9 & 1.1 \\
\hline 80 & Q9LEJO & EN01_HEVBR & Enolase 1 OS=Hevea brasiliensis & 12.2 & 49 & 6 & 47.80 & 5.57 & 53.1 & 5.4 & 2.1 \\
\hline 81 & Q42290 & MPPB_ARATH & $\begin{array}{l}\text { Probable mitochondrial-processing peptidase } \\
\text { subunit beta OS=Arabidopsis thaliana }\end{array}$ & 12.9 & 62 & 8 & 59.12 & 6.3 & 59.2 & 5.6 & 1.0 \\
\hline 82 & Q38858 & CALR2_ARATH & Calreticulin-2 OS=Arabidopsis thaliana & 11.3 & 53 & 6 & 48.12 & 4.37 & 57.6 & 4.4 & -1.0 \\
\hline 83 & 004151 & CALR1_ARATH & Calreticulin-1 OS=Arabidopsis thaliana & 14.0 & 57 & 8 & 48.49 & 4.46 & 62.3 & 4.4 & 1.0 \\
\hline 84 & Q8L6Y7 & PP193_ARATH & $\begin{array}{l}\text { Pentatricopeptide repeat-containing protein } \\
\text { At2g38420, mitochondrial OS=Arabidopsis } \\
\text { thaliana }\end{array}$ & 10.5 & 57 & 6 & 51.56 & 6.3 & 57.2 & 4.9 & -1.1 \\
\hline 85 & Q9SRG3 & PDI12_ARATH & $\begin{array}{l}\text { Protein disulfide isomerase-like 1-2 } \\
\text { OS=Arabidopsis thaliana }\end{array}$ & 8.8 & 57 & 5 & 56.32 & 4.9 & 65.1 & 4.8 & 1.0 \\
\hline 86 & 049048 & VPS45_ARATH & $\begin{array}{c}\text { Vacuolar protein sorting-associated protein } 45 \\
\text { homolog OS=Arabidopsis thaliana }\end{array}$ & 10.6 & 66 & 7 & 64.90 & 6.22 & 61.7 & 4.9 & 1.5 \\
\hline 87 & P29197 & CH60A_ARATH & $\begin{array}{c}\text { Chaperonin CPN60, mitochondrial OS=Arabidopsis } \\
\text { thaliana }\end{array}$ & 7.9 & 76 & 6 & 61.24 & 5.66 & 65.6 & 5.1 & \\
\hline 88 & P29828 & PDI_MEDSA & Protein disulfide-isomerase OS=Medicago sativa & 1.8 & 56 & 1 & 57.05 & 4.98 & 62.9 & 4.7 & 1.7 \\
\hline $89 b$ & Q39291 & VATA_BRANA & $\begin{array}{l}\text { V-type proton ATPase catalytic subunit A } \\
\text { OS=Brassica napus }\end{array}$ & 22.4 & 67 & 15 & 68.68 & 5.19 & 74.3 & 5 & 1.9 \\
\hline & Q39043 & MD37F_ARATH & $\begin{array}{l}\text { Mediator of RNA polymerase II transcription } \\
\text { subunit } 37 f \text { OS=Arabidopsis thaliana }\end{array}$ & 22.3 & 94 & 21 & 73.51 & 5.11 & 92.5 & 4.9 & \\
\hline
\end{tabular}




\begin{tabular}{|c|c|c|c|c|c|c|c|c|c|c|c|}
\hline 91 & P11143 & HSP70_MAIZE & Heat shock 70 kDa protein OS=Zea mays & 10.7 & 84 & 9 & 70.52 & 5.22 & 78 & 4.9 & 1.6 \\
\hline 92 & Q10MJ1 & CGEP_ORYS] & $\begin{array}{l}\text { Probable glutamyl endopeptidase, chloroplastic } \\
\text { OS=0ryza sativa subsp. japonica }\end{array}$ & 1.9 & 104 & 2 & 10.38 & 5.66 & 113.7 & 4.9 & 2.6 \\
\hline 93 & 082663 & DHSA1_ARATH & $\begin{array}{l}\text { Succinate dehydrogenase [ubiquinone] flavo- } \\
\text { protein subunit 1, mitochondrial OS=Arabidopsis } \\
\text { thaliana }\end{array}$ & 7.4 & 68 & 5 & 69.61 & 5.86 & 76.3 & 5.3 & 1.8 \\
\hline 94 & 004499 & PMG1_ARATH & $\begin{array}{l}\text { 2,3-bisphosphoglycerate-independent phospho- } \\
\text { glycerate mutase } 1 \text { OS=Arabidopsis thaliana }\end{array}$ & 4.9 & 61 & 3 & 60.54 & 5.32 & 68.4 & 5.3 & -1.2 \\
\hline 95 & 050008 & METE1_ARATH & $\begin{array}{c}\text { 5-methyltetrahydropteroyltriglutamate--homo- } \\
\text { cysteine methyltransferase } 1 \text { OS=Arabidopsis } \\
\text { thaliana }\end{array}$ & 17.2 & 87 & 15 & 84.30 & 6.09 & 89.6 & 5.8 & -3.4 \\
\hline 96 & 050008 & METE1_ARATH & $\begin{array}{c}\text { 5-methyltetrahydropteroyltriglutamate--homo- } \\
\text { cysteine methyltransferase } 1 \text { OS=Arabidopsis } \\
\text { thaliana }\end{array}$ & 19.5 & 87 & 17 & 84.30 & 6.09 & 89.3 & 5.8 & -4.1 \\
\hline 97 & 050008 & METE1_ARATH & $\begin{array}{c}\text { 5-methyltetrahydropteroyltriglutamate--homo- } \\
\text { cysteine methyltransferase } 1 \text { OS=Arabidopsis } \\
\text { thaliana }\end{array}$ & 17.2 & 87 & 15 & 84.30 & 6.09 & 88.6 & 5.8 & -2.8 \\
\hline 98 & Q9SRV5 & METE2_ARATH & $\begin{array}{c}\text { 5-methyltetrahydropteroyltriglutamate--homo- } \\
\text { cysteine methyltransferase } 2 \text { OS=Arabidopsis } \\
\text { thaliana }\end{array}$ & 17.0 & 88 & 15 & 84.53 & 6.09 & 88.8 & 6.1 & -1.4 \\
\hline 99 & P09801 & VCLB_GOSHI & Vicilin C72 OS=Gossypium hirsutum & 5.7 & 87 & 5 & 69.68 & 7.87 & 74.1 & 7.1 & -1.9 \\
\hline 100 & Q00624 & ASOL_BRANA & L-ascorbate oxidase homolog OS=Brassica napus & 22.8 & 57 & 13 & 62.09 & 8.9 & 76.8 & 7.9 & -2.5 \\
\hline 101 & A8MRM1 & RLF16_ARATH & Protein RALF-like 16 OS=Arabidopsis thaliana & 33.3 & 12 & 4 & 10.66 & 7.64 & 10.2 & 7 & 2.7 \\
\hline 102 & Q9FHD5 & CRR57_ARATH & $\begin{array}{c}\text { Cysteine-rich repeat secretory protein } 57 \\
\text { OS=Arabidopsis thaliana }\end{array}$ & 22.7 & 22 & 5 & 31.85 & 5.56 & 37.2 & 5.8 & 3.2 \\
\hline 103 & P13911 & RPOA_PEA & $\begin{array}{l}\text { DNA-directed RNA polymerase subunit alpha } \\
\text { OS=Pisum sativum }\end{array}$ & 16.3 & 43 & 7 & 38.90 & 7.2 & 36.9 & 5.7 & 7.4 \\
\hline 104 & Q38799 & ODPB1_ARATH & $\begin{array}{l}\text { Pyruvate dehydrogenase E1 component subunit } \\
\text { beta-1, mitochondrial OS=Arabidopsis thaliana }\end{array}$ & 15.0 & 40 & 6 & 39.15 & 5.67 & 36.1 & 5 & 3.2 \\
\hline
\end{tabular}




\section{SUPPLEMENT 2}

\begin{tabular}{|c|c|c|c|c|c|c|c|}
\hline \multirow[b]{2}{*}{ Description } & \multirow[b]{2}{*}{ Entry } & \multicolumn{2}{|c|}{ Hand-collected pollen } & \multicolumn{2}{|c|}{ Bee-collected pollen } & \multicolumn{2}{|c|}{ Honey } \\
\hline & & $\begin{array}{c}\text { Coverage } \\
(\%)\end{array}$ & $\begin{array}{c}\text { Amount } \\
(\mathrm{fmol})\end{array}$ & Coverage (\%) & Amount (fmol) & $\begin{array}{l}\text { Coverage } \\
(\%)\end{array}$ & $\begin{array}{c}\text { Amount } \\
\text { (fmol) }\end{array}$ \\
\hline $\begin{array}{c}\text { BnaC04g16060D protein OS } \\
\text { Brassica napus }\end{array}$ & A0A078C2W4_BRANA & 60.1942 & 7.4521 & 63.1068 & 7.4521 & 42.7184 & 3.5109 \\
\hline $\begin{array}{c}\text { BnaA03g28400D protein OS } \\
\text { Brassica napus }\end{array}$ & A0A078CBH7_BRANA & 72.4183 & 0 & 70.719 & 0 & 44.0523 & 1.5619 \\
\hline $\begin{array}{c}\text { BnaA01g01570D protein OS } \\
\text { Brassica napus }\end{array}$ & A0A078CFF0_BRANA & & & & & 26.3333 & 8.0721 \\
\hline $\begin{array}{c}\text { BnaA03g29240D protein OS } \\
\text { Brassica napus }\end{array}$ & A0A078CGN6_BRANA & 55.9633 & 36.8737 & 72.9358 & 36.8737 & 37.156 & 0 \\
\hline $\begin{array}{c}\text { Triosephosphate isomerase OS } \\
\text { Brassica napus }\end{array}$ & A0A078CJ83_BRANA & 71.2598 & 8.0569 & 71.6535 & 7.5337 & 38.5827 & 3.9513 \\
\hline $\begin{array}{c}\text { BnaA01g04240D protein OS } \\
\text { Brassica napus }\end{array}$ & A0A078CJM4_BRANA & & & & & 23.7113 & 1.2064 \\
\hline $\begin{array}{c}\text { BnaA03g06790D protein OS } \\
\text { Brassica napus }\end{array}$ & A0A078CPV5_BRANA & 72.2876 & 43.8474 & 75.817 & 37.3449 & 50.9804 & 5.5425 \\
\hline $\begin{array}{c}\text { BnaC08g37340D protein OS } \\
\text { Brassica napus }\end{array}$ & A0A078CYF5_BRANA & 36.3128 & 27.4707 & 62.5698 & 27.4707 & 22.905 & 2.7887 \\
\hline $\begin{array}{c}\text { BnaC09g06400D protein OS } \\
\text { Brassica napus }\end{array}$ & A0A078CZ01_BRANA & & & & & 47.4227 & 5.249 \\
\hline $\begin{array}{c}\text { BnaC07g28960D protein OS } \\
\text { Brassica napus }\end{array}$ & A0A078CZPO_BRANA & & & & & 0.883 & 11.0073 \\
\hline $\begin{array}{c}\text { BnaC08g17860D protein OS } \\
\text { Brassica napus }\end{array}$ & A0A078D684_BRANA & 46.2857 & 3.2642 & 46.2857 & 3.2642 & 11.4286 & 2.7911 \\
\hline $\begin{array}{c}\text { BnaC07g25330D protein OS } \\
\text { Brassica napus }\end{array}$ & A0A078D7Z6_BRANA & 62.234 & 43.9519 & 62.0567 & 43.9519 & 16.6667 & 4.5353 \\
\hline $\begin{array}{c}\text { BnaA06g31290D protein OS } \\
\text { Brassica napus }\end{array}$ & A0A078DBI5_BRANA & 56.5141 & 35.5261 & 56.5141 & 35.5261 & 16.9014 & 2.9526 \\
\hline Malic enzyme OS Brassica napus & A0A078DLS5_BRANA & & & & & 22.9592 & 1.232 \\
\hline $\begin{array}{c}\text { BnaA08g18150D protein OS } \\
\text { Brassica napus }\end{array}$ & A0A078DNT9_BRANA & 63.1579 & 52.8471 & 73.0994 & 52.2726 & 35.6725 & 0 \\
\hline $\begin{array}{c}\text { BnaA03g26250D protein OS } \\
\text { Brassica napus }\end{array}$ & A0A078DNY7_BRANA & 43.6709 & 20.3399 & 43.6709 & 20.3399 & 15.1899 & 2.2399 \\
\hline Malic enzyme OS Brassica napus & A0A078DRQ2_BRANA & & & & & 11.0544 & 0.4181 \\
\hline $\begin{array}{c}\text { BnaC03g33530D protein OS } \\
\text { Brassica napus }\end{array}$ & A0A078DS18_BRANA & 72.4183 & 26.6452 & & & 43.3987 & 0 \\
\hline $\begin{array}{c}\text { BnaC01g11000D protein OS } \\
\text { Brassica napus }\end{array}$ & AOA078EEH5_BRANA & 79.6512 & 27.7614 & 48.8372 & 24.9081 & 33.1395 & 8.4917 \\
\hline $\begin{array}{c}\text { BnaC06g28200D protein OS } \\
\text { Brassica napus }\end{array}$ & A0A078EI76_BRANA & & & & & 6.0567 & 0.152 \\
\hline $\begin{array}{c}\text { BnaC02g07610D protein OS } \\
\text { Brassica napus }\end{array}$ & A0A078EPU3_BRANA & 67.451 & 25.1671 & 69.9346 & 24.5928 & 45.2288 & 4.9973 \\
\hline $\begin{array}{c}\text { BnaC01g16500D protein OS } \\
\text { Brassica napus }\end{array}$ & A0A078EQS9_BRANA & 91.2568 & 55.3382 & 75.9563 & 55.3382 & 74.3169 & 7.171 \\
\hline $\begin{array}{c}\text { BnaA07g14060D protein OS } \\
\text { Brassica napus }\end{array}$ & A0A078ERR4_BRANA & 63.764 & 0.7921 & 63.764 & 0.9641 & 19.9438 & 1.3396 \\
\hline $\begin{array}{c}\text { BnaA07g13000D protein OS } \\
\text { Brassica napus }\end{array}$ & A0A078EV53_BRANA & 73.1544 & 56.1043 & 73.1544 & 56.0589 & 61.745 & 5.3308 \\
\hline $\begin{array}{c}\text { BnaAnng00740D protein OS } \\
\text { Brassica napus }\end{array}$ & A0A078EV77_BRANA & 41.3245 & 14.5407 & 42.1192 & 14.0971 & 9.2715 & 1.5774 \\
\hline $\begin{array}{c}\text { BnaC02g38360D protein OS } \\
\text { Brassica napus }\end{array}$ & A0A078EWU2_BRANA & 65.4912 & 71.9718 & 59.194 & 71.9718 & 16.1209 & 1.0456 \\
\hline $\begin{array}{c}\text { BnaA02g31820D protein OS } \\
\text { Brassica napus }\end{array}$ & A0A078EY46_BRANA & & & & & 0.8282 & 3.4022 \\
\hline $\begin{array}{c}\text { BnaC05g04310D protein OS } \\
\text { Brassica napus }\end{array}$ & A0A078FDN9_BRANA & 18.3673 & 0.8807 & 18.3673 & 0.8446 & 9.9125 & 5.1398 \\
\hline
\end{tabular}


BnaC07g15930D protein OS Brassica napus

BnaA02g12590D protein OS Brassica napus

BnaC08g40620D protein OS Brassica napus

BnaA02g12130D protein OS Brassica napus

BnaC09g36920D protein OS Brassica napus

BnaA09g06900D protein OS Brassica napus

BnaA01g26720D protein OS Brassica napus

BnaC08g13830D protein OS Brassica napus

BnaC04g36920D protein OS Brassica napus

Lactoylglutathione lyase OS Brassica napus

BnaC01g39610D protein OS Brassica napus

BnaC01g39620D protein OS Brassica napus

BnaA06g37080D protein OS Brassica napus

BnaC05g39930D protein OS Brassica napus

Malate dehydrogenase OS Brassica napus

BnaA07g02960D protein OS Brassica napus

BnaC03g17030D protein OS Brassica napus

BnaC05g34710D protein OS Brassica napus

BnaA02g10950D protein OS Brassica napus

BnaC09g42270D protein OS Brassica napus

Malate dehydrogenase OS Brassica napus

BnaC06g02730D protein OS Brassica napus

BnaA06g25580D protein OS Brassica napus

BnaA02g25430D protein OS Brassica napus

BnaA03g49470D protein OS Brassica napus

BnaA09g16230D protein OS Brassica napus

BnaC08g41860D protein OS Brassica napus

BnaA09g47550D protein OS Brassica napus

BnaC09g37570D protein OS Brassica napus

BnaA01g14010D protein OS Brassica napus

BnaA03g11410D protein OS Brassica napus

BnaC06g03590D protein OS Brassica napus
AOA078FEN2_BRANA

A0A078FHF1_BRANA

A0A078FSK2_BRANA

A0A078FTY1_BRANA

A0A078FUC5_BRANA

A0A078FW97_BRANA

A0A078G1R2_BRANA

A0A078G2DO_BRANA

A0A078G4E6_BRANA

A0A078G6I2_BRANA

A0A078G6P5_BRANA

A0A078G9V9_BRANA

A0A078GAH2_BRANA

A0A078GE19_BRANA

A0A078GG36_BRANA

A0A078GG58_BRANA

A0A078GH67_BRANA

AOA078GIN3_BRANA

A0A078GKL6_BRANA

A0A078GM91_BRANA

A0A078GMM3_BRANA

A0A078GSI3_BRANA

A0A078GVL8_BRANA

A0A078GWDO_BRANA

AOA078H057_BRANA

A0A078H2Z2_BRANA

A0A078HAB6_BRANA

A0A078HBG6_BRANA

AOA078HBPO_BRANA

A0A078HBY7_BRANA

AOA078HEF2_BRANA

A0A078HFH3_BRANA $\begin{array}{ll}40.9211 & 2.0944 \\ 76.5306 & 4.0066 \\ 44.4444 & 60.6021\end{array}$

$4 \quad 0.968$

$9.4309 \quad 1.4866$

$48.1959 \quad 7.6627$

$9.8196 \quad 1.0149$

$3.1042 \quad 2.4954$

$\begin{array}{llllll}48.954 & 21.0095 & 48.954 & 21.0095 & 38.0753 & 1.2826\end{array}$

$27.5618 \quad 3.4529$

$\begin{array}{llllll}67.7582 & 80.3766 & 67.7582 & 80.3766 & 59.9496 & 27.6636\end{array}$

$56.546 \quad 0$

$51.8519 \quad 4.2187$

$3.4591 \quad 55.5784$

$\begin{array}{llllll}70.8823 & 9.1554 & 70.8823 & 12.2704 & 56.4706 & 1.546\end{array}$

$16.4063 \quad 1.7875$

$3.5294 \quad 2.3993$

$34.4196 \quad 6.1036$

$2.4938 \quad 1.0046$

$1.3699 \quad 0.7787$

$\begin{array}{llllll}80.9384 & 25.2233 & 79.1789 & 6.162 & 56.305 & 3.4602\end{array}$

$\begin{array}{llllll}77.8846 & 27.3447 & 77.4038 & 27.3447 & 23.5577 & 1.807\end{array}$

$7.045 \quad 2.3227$

$20.1681 \quad 1.0443$

$10.3704 \quad 0$

$8.9431 \quad 1.0999$

$\begin{array}{llllll}56.4486 & 5.6147 & 42.8037 & 6.0681 & 16.0748 & 1.6376\end{array}$

$\begin{array}{llllll}63.9405 & 16.1599 & 56.8773 & 15.7065 & 23.6059 & 2.1135\end{array}$

$8.2687 \quad 0.0903$

$\begin{array}{llllll}91.2568 & 36.7332 & 75.9563 & 36.7332 & 74.3169 & 10.9305\end{array}$

$44.4444 \quad 83.0132$

$85.1852 \quad 0.6324$ 


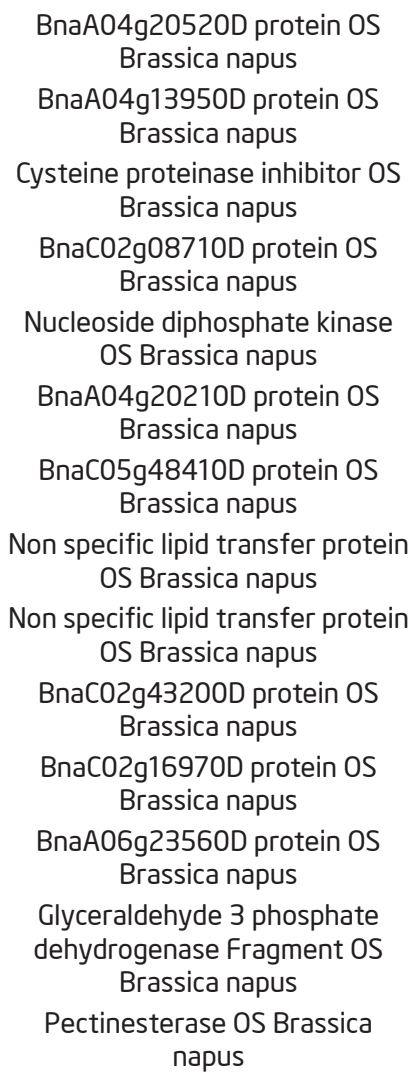
mellifera

Uncharacterized protein OS Apis mellifera

Uncharacterized protein OS Apis mellifera

Uncharacterized protein OS Apis mellifera

Uncharacterized protein OS Apis mellifera

Uncharacterized protein OS Apis mellifera

Uncharacterized protein OS Apis mellifera

Uncharacterized protein OS Apis mellifera

Uncharacterized protein OS Apis mellifera

Uncharacterized protein OS Apis mellifera

Uncharacterized protein OS Apis mellifera

Uncharacterized protein OS Apis mellifera

Uncharacterized protein OS Apis mellifera

Uncharacterized protein OS Apis mellifera
A0A078HPI7_BRANA

AOA078HSFO_BRANA

A0A078HUB5_BRANA

A0A078HUR8_BRANA

A0A078HV31_BRANA

A0A078HYN8_BRANA

A0A078I298_BRANA

A0A078I7E1_BRANA

A0A078I7RO_BRANA

A0A078I9J4_BRANA

A0A078IHY1_BRANA

AOA078IJR4_BRANA

A0A078IJWO_BRANA

A0A078IK58_BRANA

A0A078J819_BRANA

A0A078JFE6_BRANA

AOA078JFPO_BRANA

A0A078K080_BRANA

A0A087ZR10_APIME

A0A087ZRC8_APIME

A0A087ZSJO_APIME

A0A087ZSJ1_APIME

A0A087ZVX2_APIME

A0A087ZVX4_APIME

A0A087ZWK4_APIME

A0A087ZXA0_APIME

A0A087ZXA2_APIME

A0A087ZYX8_APIME

A0A088A030_APIME

A0A088A031_APIME

A0A088A3F5_APIME

A0A088A4K9_APIME
17.3333

5.0177

38.0753

4.6976

22.0588

25.5319

2.3338

1.6099

19.1176

1.0753

$74.3243 \quad 18.9886 \quad 74.3243$

4.6653

25.5319

1.5782

$15.7224 \quad 13.5135$

2.29

6.7164

1.988

56.3025

16.0494

0

4.3583

$\begin{array}{llll}49.1667 & 5.5197 & 49.1667 & 5.5197\end{array}$

49.1667

24.971

35.4756

0.2601

76.5306

1.0341

$44.8718 \quad 7.5963$

$85.119 \quad 31.9453$

85.119

7.9288

55.6548

12.3664

$14.5648 \quad 3.1886$

$7.8571 \quad 3.1706$

$\begin{array}{llllll}88.2682 & 26.359 & 88.2682 & 26.2954 & 10.8939 & 1.4896\end{array}$

$12.6437 \quad 0.2728$

$\begin{array}{llllll}76.9231 & 2.8346 & 75.2137 & 3.1489 & 40.1709 & 0.4667\end{array}$

$31.25 \quad 5.3396$

$20.2667 \quad 1.9393$

$47.4747 \quad 48.4586$

$62.766 \quad 43.1387$

$65.8462 \quad 9.9438$

$12.0579 \quad 2.2705$

$76.1578 \quad 198.1699$

$58.2237 \quad 17.6406$

$43.5644 \quad 10.1937$

$18.2716 \quad 1.6879$

$42.1384 \quad 18.509$

$47.6423 \quad 41.7336$

$65.3659 \quad 0$

$70.7692 \quad 6.6022$ 
Carboxylic ester hydrolase OS Apis mellifera

Uncharacterized protein OS Apis mellifera

Uncharacterized protein OS Apis mellifera

Uncharacterized protein OS Apis mellifera

Transferrin OS Apis mellifera

Uncharacterized protein OS Apis mellifera

Uncharacterized protein OS Apis mellifera

Glucosylceramidase OS Apis mellifera

Glucosylceramidase OS Apis mellifera

Uncharacterized protein OS Apis mellifera

Uncharacterized protein OS Apis mellifera

Uncharacterized protein OS Apis mellifera

Uncharacterized protein OS Apis mellifera

Uncharacterized protein OS Apis mellifera

Uncharacterized protein OS Apis mellifera

Uncharacterized protein OS Apis mellifera

Uncharacterized protein OS Apis mellifera

Polygalacturonase inhibitor protein 15 OS Brassica napus

Major royal jelly protein 8 OS Apis mellifera

Major royal jelly protein 1 OS Apis mellifera

Major royal jelly protein 2 OS Apis mellifera

Major royal jelly protein 4 OS Apis mellifera

MRJP5 OS Apis mellifera

Hexamerin 110 OS Apis mellifera

Alcohol dehydrogenase 1 OS

Saccharomyces cerevisiae strain ATCC 204508 S288c

Alpha glucosidase OS Apis mellifera

Major royal jelly protein 30 S

Apis mellifera carnica

Chemosensory protein 1 OS Apis mellifera

Major royal jelly protein 9 OS Apis mellifera

Major royal jelly protein 7 OS Apis mellifera

Major royal jelly protein MRJP6 OS Apis mellifera

Polygalacturonase OS Brassica napus
A0A088A5D7_APIME

A0A088A9G7_APIME

A0A088AC16_APIME

A0A088ADM5_APIME

A0A088AFH7_APIME

A0A088AJR6_APIME

A0A088AMK2_APIME

A0A088APM4_APIME

A0A088APM5_APIME

A0A088AQK1_APIME

A0A088ARX6_APIME

A0A088ASF2_APIME

A0A088AU20_APIME

A0A088AU21_APIME

A0A088AU22_APIME

A0A088AU26_APIME

A0A088AU27_APIME

A9YBZ6_BRANA

B3GM11_APIME

C6K481_APIME

C6K482_APIME

D3JXA7_APIME

D3JZ08_APIME

D3KZF8_APIME

ADH1_YEAST

Q25BT6_APIME

Q3L632_APICA

Q3LBA7_APIME

Q4ZJX1_APIME

Q6IMJ9_APIME

Q6W3E3_APIME

Q7Y1T6_BRANA
45.9313

13.188

6.0841

7.1801

47.5138

22.8407

52.9745

11.8234

46.3483

0

22.54

8.0861

21.1581

2.9243

41.5709

11.4653

42.2701

15.6591

29.5238

1.3666

7.7236

1.3544

13.3038

1.3003

51.7241

16.6315

68.4211

16.5041

68.0191

39.897

83.8235

1.4387

76.4045

10.4338

42.6513

1.5934

44.6686

1.5934

36.0231

0.6289

10.3614

1.4027

86.3426

265.2684

84.5133

267.9784

52.3707

10.4773

56.3545

133.1504

18.57

0

46.5517

25

46.5517

25

34.1954

25

78.3069

17.5721

65.1123

18.3481

42.2414

1.8087

35.6974

12.0965

77.2009

131.8121

68.4211

59.2834

68.0101

53.2394

68.0101

53.1486

13.8384 
_ BORUIINSKHIIE Et HL. _ _ Rape pollen and honey proteomic analysis

Polygalacturonase inhibitory protein Fragment OS Brassica napus

Alpha amylase OS Apis mellifera mellifera

Q8LJS4_BRANA

60.3226

9.2852

62.5806

9.2852

34.1936

0.8992

Q8N0N7_APIME

69.7769

16.5656

Alpha amylase OS Apis mellifera 